NBER WORKING PAPER SERIES

\title{
LONG-RUN PRICE ELASTICITIES OF DEMAND FOR CREDIT: EVIDENCE FROM A COUNTRYWIDE FIELD EXPERIMENT IN MEXICO
}

\author{
Dean Karlan \\ Jonathan Zinman \\ Working Paper 19106 \\ http://www.nber.org/papers/w19106
NATIONAL BUREAU OF ECONOMIC RESEARCH
1050 Massachusetts Avenue
Cambridge, MA 02138
June 2013

Thanks to Kerry Brennan, Angela Garcia Vargas, Matt Grant, Kareem Haggag and Rachel Strohm for excellent project management and research assistance, and to Alissa Fishbane, Braulio Torres and Anna York from Innovations for Poverty Action for leadership of IPA-Mexico. Thanks to Abhijit Banerjee, Esther Duflo, Jake Kendall, Melanie Morten, David Roodman Chris Snyder and participants in seminars at M.I.T./Harvard and NYU for comments. Thanks to CGAP, in particular Richard Rosenberg, and the Bill and Melinda Gates Foundation for funding support. Thanks to the management and staff of Compartamos Banco for their cooperation. Authors retained complete intellectual freedom to report and interpret the results. Any opinions, errors or omissions are those of the authors. The views expressed herein are those of the authors and do not necessarily reflect the views of the National Bureau of Economic Research.

NBER working papers are circulated for discussion and comment purposes. They have not been peerreviewed or been subject to the review by the NBER Board of Directors that accompanies official NBER publications.

(C) 2013 by Dean Karlan and Jonathan Zinman. All rights reserved. Short sections of text, not to exceed two paragraphs, may be quoted without explicit permission provided that full credit, including $\odot$ notice, is given to the source. 
Long-Run Price Elasticities of Demand for Credit: Evidence from a Countrywide Field Experiment in Mexico

Dean Karlan and Jonathan Zinman

NBER Working Paper No. 19106

June 2013

JEL No. E43,G21,O11,O12

\begin{abstract}
The long-run price elasticity of demand for credit is a key parameter for intertemporal modeling, policy levers, and lending practice. We use randomized interest rates, offered across 80 regions by Mexico's largest microlender, to identify a 29-month dollars-borrowed elasticity of -1.9. This elasticity increases from -1.1 in year one to -2.9 in year three. The number of borrowers is also elastic. Credit bureau data does not show evidence of crowd-out. Competitors do not respond by reducing rates, perhaps because Compartamos' profits are unchanged. The results are consistent with multiple equilibria in loan pricing.
\end{abstract}

Dean Karlan

Department of Economics

Yale University

P.O. Box 208269

New Haven, CT 06520-8629

and NBER

dean.karlan@yale.edu

Jonathan Zinman

Department of Economics

Dartmouth College

314 Rockefeller Hall

Hanover, NH 03755

and NBER

jzinman@dartmouth.edu 
Price elasticities of demand for credit are key parameters for intertemporal modeling, policy levers, and lending practice. On the modeling side, credit elasticities can shed light on liquidity constraints, returns to capital, and other elements of choice sets that drive elasticities of intertemporal substitution (Attanasio and Weber 2010). Such elasticities are key inputs for monetary and fiscal policies, as well as for micro-development policies. For example, policymakers and donors promoting financial development have variously encouraged microfinance financial institutions (MFIs) to cut rates to expand access under the assumption of elastic demand, or to raise rates to decrease reliance on subsidies under the assumption of inelastic demand (Rosenberg (2002)).

Yet evidence on credit price elasticities is limited, particularly over longer time horizons. Long-run elasticities can differ from short-run elasticities for several reasons. On the borrower side, consumers may take time to learn about new rates, to adjust their choice sets (e.g., credit constraints may be less binding when borrowers have more time to search or plan), or to adjust their production functions (fixed costs become variable in the long-run). On the lender side, competitors may respond to a single lender's price change, but not immediately (due, e.g., to menu costs, agency costs, and/or uncertainty about whether the first mover's price change is temporary or permanent).

We worked with Compartamos Banco, a for-profit, publicly-traded bank and the largest microlender ${ }^{2}$ in Mexico, to estimate price general-equilibrium, longrun (as well as short-run) price elasticities by randomizing the interest rate offered

\footnotetext{
${ }^{2}$ Microlending is typically defined as the provision of small-dollar loans to (aspiring) entrepreneurs, although there is some policy and practitioner debate over the definition, see Karlan and Morduch (2009) and Armendariz de Aghion and Morduch (2010) for reviews.
} 
on its core group lending product, Credito Mujer ${ }^{3}$ Compartamos randomized at the level of 80 distinct geographic regions throughout Mexico, covering 130 field offices, thousands of borrowing groups, and tens of thousands of borrowers. "Treatment" branches implemented permanent 20 percentage point (pp) reductions in the annual interest rate (on a base of roughly 100\% APR), while control branches implemented permanent 10pp reductions. We then estimate elasticities (and other treatment effects) using administrative data from Compartamos and credit bureaus over various horizons, for up to 29 months posttreatment. These elasticities are identified under the assumption that the treatment did not induce differential supply-side changes; e.g., we assume that screening, monitoring, and marketing did not differ across treatment and control groups. The screening and monitoring assumptions are supported by the finding that the lower rate does not affect delinquency rates. The marketing assumption seems plausible given study protocols and the fact that both treatment and control regions experienced rate cuts (20pp vs. $10 \mathrm{pp})$ relative to Compartamos' prior rate.

The research design here has some advantages compared to the most closely related prior studies. It allows more time for consumer learning and competitor response than the randomized direct mail studies used in Ausubel (1999) and Karlan and Zinman (2008). It uses non-subsidized and permanent price changes (see Bengtsson and Pettersson (2012) for evidence based on a transitory and subsidized zero interest rate). And our design uses randomized variation, over

\footnotetext{
${ }^{3}$ For annual and other reports from 2010 onward, see http://www.compartamos.com/wps/portal/Grupo/InvestorsRelations/FinancialInformation
} 
many more geographic areas, than the quasi-experimental, 3-cluster design of Dehejia et al (2012). ${ }^{4}$

We start by examining the extensive margin of demand, and find average elasticities (over the entire 29-month experiment) of loans taken out with respect to interest rates of around -1.4 in various specifications. We find some evidence that the lower interest rate attract new borrowers, irrespective of education and income, suggesting that lower prices may be effective at expanding access and not just for higher-income or -education individuals. This is an important result from a policy perspective, as depth of outreach to disadvantaged populations is an important consideration for regulators, donors and socially-motivated investors.

We also find very elastic demand with respect to the amount borrowed (which combines extensive and intensive margins). The average price elasticity is around -1.9 in various specifications. Elasticities increase sharply in absolute value over time, from -1.1 for the first year post-price change to -2.9 for the third year.

We address general equilibrium dynamics of the average elasticities in three ways. First, using credit bureau data, we examine how much of the increase in borrowing with Compartamos represents net new borrowing (vs. business-stealing from competitors) and find no evidence of crowd-out. (If anything, the point estimates suggest crowd-in.) Second, randomizing at the level of large geographic units (our 80 regions) internalizes any within-region feedback effects of price changes on supplier pricing, wages, etc. (However, we do not have any way of identifying whether and to what extent such feedback matters.) Third, we directly examine competitor offerings over a 20 -month horizon and find no evidence that competitors responded differentially in Compartamos' lower-rate areas.

\footnotetext{
${ }^{4}$ Other quasi-experimental studies include Gross and Souleles (2002) on credit cards in the United States, Alessie et al (2005) on consumer loans in Italy, and Attanasio et al (2008) on auto loans in the United States.
} 
Why don't competitors respond if demand is elastic? A null effect on Compartamos' profits provides a piece of the puzzle. Delinquency does not fall significantly at lower rates, although our confidence intervals do not rule out economically significant reductions that would be consistent with lower rates (further) mitigating information asymmetries. ${ }^{5}$ The bank's other costs for treatment areas - namely, operating costs-- rose significantly and offset any increase in gross interest income. ${ }^{6}$ In all, the results suggest that multiple pricing equilibria are possible and sustainable. ${ }^{7}$

Summarizing our key results, we find that long-run demand is price elastic, with elasticities growing over time and no evidence of crowd-out. Lower prices bring in substantial numbers of new borrowers, and not differentially with respect to income or education. But the lower rates do not increase profits, as the costs of servicing additional clients offset any increase in revenues. Competitors do not respond to Compartamos' lower prices. Overall, we find that Compartamos has sustainably served more clients by cutting rates, at no cost to shareholders.

\footnotetext{
${ }^{5}$ See also Karlan and Zinman (2009), which finds evidence of substantial information asymmetries in individual liability consumer lending in South Africa.

${ }^{6}$ It is possible that the increased number of clients has led to increased profits from crosssells, but we lack data to estimate that effect.

${ }^{7}$ To be clear, we cannot test precisely for multiple equilibria: there may be one equilibrium in between the two points we test where our two points are simply equivalent in terms of profit but not actually equilibria; there may be a continuum of equilibria that contain both of the two points we test; there may be truly two (or more) unique equilibria, at the two points we tested (or more); or, it may simply be that despite the large shift in revenue between our two points, the empirical precision on profits is too noisy to isolate the precise equilibrium.
} 


\section{The Market Setting}

\section{A. Compartamos and its Target Market}

The lender, Compartamos Banco, is the largest microlender in Mexico with 2.3 million borrowers. ${ }^{8}$ Compartamos was founded in 1990 as a nonprofit organization, converted to a commercial bank in 2006, went public in 2007, and has a market capitalization of US $\$ 2.2$ billion as of November $16^{\text {th }}, 2012$. As of 2012, 71\% of Compartamos clients borrow through Crédito Mujer, the group microloan product studied in this paper.

Crédito Mujer nominally targets women that have a business or selfemployment activity or intend to start one. Empirically, 100\% of borrowers are women, but a companion paper uses survey data to estimate that only about $52 \%$ are "microentrepreneurs" (Angelucci, Karlan, and Zinman 2013). Borrowers tend to lack the income and/or collateral required to qualify for loans from banks and other "upmarket" lenders. Below we provide additional information on marketing, group formation, and screening.

\section{B. Loan Terms}

Crédito Mujer loan amounts range from M\$900-M\$24,000 pesos (13 pesos, denoted M\$, = \$1US), with larger amounts subsequently available to members of groups that have successfully repaid prior loans. ${ }^{9}$ Loan repayments are due over 16 equal weekly installments, and are guaranteed by the group (i.e., joint

\footnotetext{
${ }^{8}$ According to Mix Market, http://www.mixmarket.org/mfi/country/Mexico, accessed August $22^{\text {nd }}, 2012$.

${ }^{9}$ Also, beginning in weeks 3 to 9 of the second loan cycle, clients in good standing can take out an additional, individual liability loan, in an amount up to $30 \%$ of their joint liability loan.
} 
liability). Aside from these personal guarantees there is no collateral. Interest rates are marketed as monthly, "add-on" rates of 3.0-4.5\%, excluding value-added tax and forced simultaneous savings. ${ }^{10}$ This pricing sits roughly in the middle of the market, both with respect to nonprofit and for-profit lenders. ${ }^{11}$

\section{Targeting, Marketing, Group Formation, and Screening ${ }^{12}$}

Crédito Mujer groups range in size from 10 to 50 members. When Compartamos enters a new market loan officers typically target self-reported female entrepreneurs and promote the Credito Mujer product through diverse channels, including door-to-door promotion, distribution of fliers in public places, radio, promotional events, etc. As loan officers gain more clients in new areas, they promote less frequently and rely more on clients to recruit other members.

When a group of about five women - half of the minimum required group size - expresses interest, a loan officer visits the partial group at one of their homes or businesses to explain loan terms and process. These initial women are responsible

\footnotetext{
${ }^{10}$ An add-on rate is calculated over the original loan amount and does not adjust for declining balances as an Annual Percentage Rate (APR) does. Borrowers must make an upfront deposit totaling $10 \%$ of their loan amount into a personal savings account, and contribute at least 10 pesos weekly for the remainder of the loan cycle. This "forced savings" component at either zero or low interest is not claimed as collateral, but rather meant to instill a "culture of regular deposits" and generate a signal of the client's ability to generate and manage cash flow that can be used to evaluate creditworthiness for future loans. The forced savings is not necessarily held by Compartamos; i.e., the effective APR paid by the borrower may be higher than the effective APR earned by Compartamos. Mexican law does not require advertisements or disclosures to include the forced savings or value-added tax in APR calculations.

${ }^{11}$ See http://blogs.cgdev.org/open_book/2011/02/compartamos-in-context.php for more details on microloan pricing in Mexico. Among other things, there does not seem to be clear relationship between lender ownership status (for-profit vs. Non-profit) and effective APRs.

${ }^{12}$ This sub-section also appears in Angelucci et al (2013).
} 
for finding the rest of the group members. The loan officer returns for a second visit to explain loan terms in greater detail and complete loan applications for each individual. All potential members must be older than 18 years and also present a proof of address and valid identification to qualify for a loan. Business activities (or plans to start one) are not verified; rather, Compartamos relies on group members to screen out any uncreditworthy applicants. In equilibrium, potential members who apply are rarely screened out by their fellow members, since individuals who would not get approved are not recruited and do not to tend to seek out membership.

Compartamos reserves the right to reject any applicant put forth by the group but relies heavily on the group's endorsement. Compartamos does pull a credit report for each individual and automatically rejects anyone with a history of fraud. Beyond that, loan officers do not use the credit bureau information to reject clients, as the group has responsibility for deciding who is allowed to join.

Applicants who pass Compartamos' screens are invited to a loan authorization meeting. Each applicant must be guaranteed by every other member of the group to get a loan. Loan amounts must also be agreed upon unanimously. Loan officers moderate the group's discussion, and sometimes provide information on credit history and assessments of individuals' creditworthiness. Proceeds from authorized loans are disbursed as checks to each client.

\section{Group Administration, Loan Repayment, and Collection Actions}

Each group elects a treasurer who collects payments, from each group member, at each weekly meeting. The loan officer is present to facilitate and monitor but does not touch the money. If a group member does not make her weekly payment, the President (and loan officer) will typically solicit and 
encourage "solidarity" pooling to cover the payment and keep the group in good standing. All payments are placed in a plastic bag that Compartamos provides, and the Treasurer then deposits the group's payment at either a nearby bank branch or convenience store. $^{13}$

Beyond the group liability, borrowers have several other incentives to repay. Members of groups with arrears are not eligible for another loan until the arrears are cured. Members of groups that remain in good standing qualify for larger subsequent loan amounts and lower interest rates. Compartamos also reports individual repayment history for each borrower to the Mexican Official Credit Bureau. Loans that are more than 90 days in arrears after the end of the loan term are sent to collection agencies.

Late payments are common, but default is rare: in our data, we find a 90-day group delinquency rate of $9.8 \%$, but the ultimate default rate is only about $1 \%$.

\section{Study Design}

The research team (IPA) worked with Compartamos to identify 80 distinct geographic areas ("regions" for the purpose of the study), throughout Mexico, for the purpose of randomly assigning interest rates (Figure 1). The Compartamos operating unit within a region is a "branch" (actually more like a regional or subregional office); the mean number of branches per region is 1.65. IPA then assigned each of the 80 regions (and all branches within each region) to either "low rate" or "high rate". The interest rates applied only to Compartamos' core

\footnotetext{
${ }^{13}$ Compartamos has partnerships with six banks (and their convenience stores) and two separate convenience stores. The banks include Banamex (Banamexi Aquí), Bancomer (Pitico), Banorte (Telecomm and Seven Eleven), HSBC, Scotiabank, and Santander. The two separate convenience stores are Oxxo and Chedraui.
} 
group lending product. Compartamos did not bundle any additional operational or strategic changes across high- vs. low-rate regions, so any responses we observe are demand-driven, pure price effects.

\section{Figure 1. Randomized Pricing by Study Region}

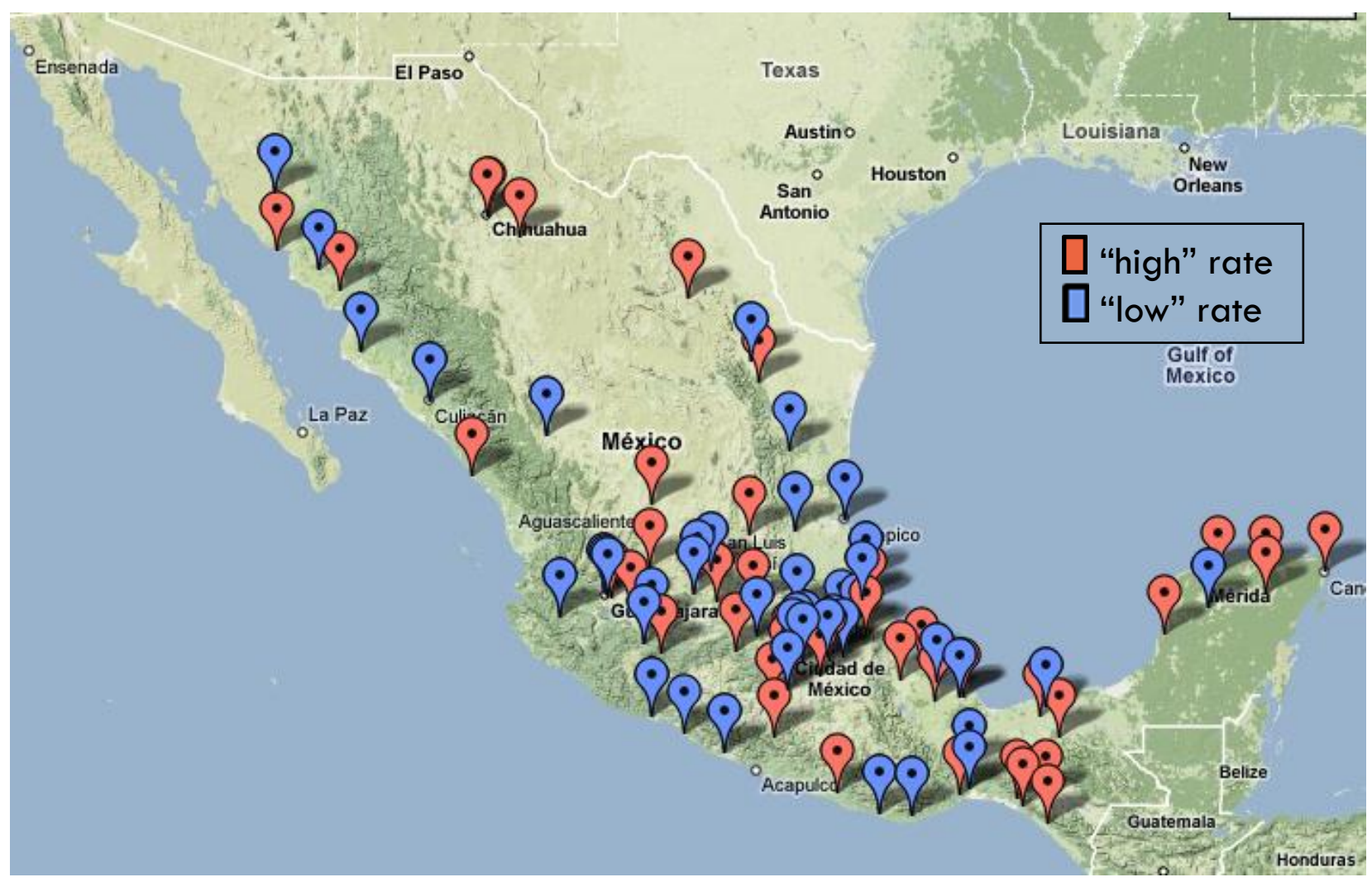

The motivation for randomizing at the region level, as opposed to a more granular level like branches or groups, is twofold. The first is to allow for any consumer learning and competitive response to take place at the level of a geographic market; i.e., we allow for within-market spillovers. Second, regionlevel assignment facilitates compliance with the randomization in a group lending setting, by ensuring that contiguous groups or contiguous branches (which would 
normally draw some borrowers from overlapping geographic areas) are assigned the same rate.

Table 1 summarizes various baseline (April 2007) averages for low-rate and high-rate regions, and checks for balance on these observables. Panel A covers borrower characteristics: education, age, number of children, number of dependents, and marital status. Panel B covers loan volume, both to all borrowers and to groups targeted by some policymakers, MFIs, and donors (new borrowers and those with low education; we also consider relatively poor borrowers below but lack pre-treatment data on income or wealth). Panel $\mathrm{C}$ covers loan characteristics: APR, loan amount, group size, and number of groups. Delinquency data is absent here because we lack the requisite data pre-treatment. Panel D covers region characteristics, focusing on Compartamos' market share as measured using credit bureau data. Overall, Table 1 suggests that the randomization is valid: we find no more significant differences across low-rate and higher-rate regions than one would expect to find by chance.

The experiment engineered prices that were about 10 percentage points lower (in APR units) in "low rate" regions (Table 2 Panel A). Starting May 15, 2007, Compartamos implemented this variation by offering differential cuts from pretreatment prices. Low-rate regions got 20 percentage point cuts from pretreatment rates (which averaged about 100\% APR, as shown in Table 1 Panel C). High-rate regions got 10 percentage point cuts. ${ }^{14}$ Compartamos presented these prices to (prospective) borrowers as "permanent" in the sense of the "new

\footnotetext{
${ }^{14}$ Compartamos advertises and administers interest rates in add-on, monthly terms, and prices each group into one of three tiers based on past performance. So the randomization assigned low-rate regions to tiered pricing of 3.0\%/3.5\%/4.0\% monthly, and high-rate regions to $3.5 \% / 4.0 \% / 4.5 \%$ monthly. We convert these monthly rates to balanceweighted APRs.
} 
normal": these were not promotional rates. The bank has kept these rates in place permanently in all study branches.

We measure price sensitivities by comparing various outcome measures in low- vs. high-rate regions for up to 29-months post-"treatment" (i.e, postdifferential rate cuts). In some cases we can use pre-treatment data as well. The next section details our specifications and results.

\section{Empirical Specifications and Results}

\section{A. Simple Means Comparisons Preview Many of the Key Results}

Table 2, Panels B-D shows simple means comparisons for key first-order (i.e., Compartamos) outcomes. Each column reports an estimated difference (and its standard error) between the mean region in the treatment (low-rate) group and the mean region in the control (higher-rate) group. Columns 1-5 report differences at six-month increments post-treatment, and Column 6 covers the entire posttreatment period. Since stocks change more slowly than flows, we focus on flows. So, e.g., Panel B Column 1 counts loans disbursed during the sixth post-treatment month. We report only differences due to space constraints, but Table 1 shows many of the pre-treatment levels.

Table 2's findings preview many of our regression results, and differ from our regressions only in that the simple means comparisons use less information: fewer post-treatment months, and no pre-treatment months.

Panel B, which counts loans disbursed, shows several key patterns. First, we see almost uniformly positive point estimates, suggesting that the lower rate does produce more borrowers. Second, we see almost uniformly elastic point 
elasticities. Third, the point estimates and elasticities get larger over time (reading from Column 1 to Column 5). Fourth, they are more likely to be significantly different from zero in the later periods (Columns 4 and 5). Fifth, the low rate produces new borrowers - those had never borrowed from Compartamos before - strongly and significantly in both the later periods and over the full posttreatment period. The point estimates are consistent with elastic responses by other commonly targeted groups - low-education and poorer borrowers-but results for these groups are imprecise, and not statistically different from high education and wealthier borrowers. ${ }^{15}$

Panel C shows similar patterns for loan amounts disbursed.

Panel D shows results for delinquencies. We would expect the lower rate to reduce delinquencies if there are information asymmetries (see Karlan and Zinman (2009) for a discussion and experiment to identify such effects). This might be particularly true for new groups or groups comprised of primarily new members, if screening is more difficult without a prior transaction history. Note that base level of delinquency is in fact high enough for interest rates to have a potentially meaningful effect on the margin: the post-treatment period control group averages are $14 \%$ for any lateness, and for $10 \%$ more than 90 days late. We do not find robust evidence of a delinquency elasticity with respect to interest rates, although most of the point estimates are negative.

Panel E shows positive but imprecisely estimated increases in interest income. Costs increase by about the same amount in point terms, but are more precisely

\footnotetext{
${ }^{15}$ In a given month, we define a loan to a new borrower as one disbursed to someone who had not borrowed from Compartamos in any previous month. We measure educational attainment for each borrower using Compartamos application data. We measure poverty likelihood (Schreiner 2006) for each borrower using application data that Compartamos starting collecting in June 2007.
} 
estimated and hence significantly different from zero. The effects on profits are imprecisely estimated zeros. Are accounting definitions of income, costs, and profits are standard, and detailed in the table notes.

\section{B. Regression Specifications, and Results on Elasticities of Loans Disbursed}

We use our analysis of loans disbursed-i.e., of loans taken out, the extensive margin of loan demand - to introduce our main empirical specifications. These regressions augment the simple means comparisons presented in Table 2 by controlling for pre-treatment data and secular time effects to improve the precision of the estimates. We do this using three different OLS specifications:

(1) $Y_{\mathrm{rt}}=\alpha+\beta^{1}\left(\right.$ LowRate $_{\mathrm{r}}$ Post $\left._{\mathrm{t}}\right)+\rho \mathrm{R}+\tau \mathrm{T}+\varepsilon$

$Y$ is an outcome (here the flow of loans disbursed), measured for region $\mathrm{r}$ in month-year t. $\alpha$ is the constant. The variable of interest here is the interaction term - which equals one if and only if the observation is from a low-rate region in the post-treatment period - and $\beta^{1}$ identifies price sensitivity. $\mathrm{R}$ is a vector of dummies - fixed effects - for each region, and $\rho$ is the vector of coefficients on these fixed effects. $\mathrm{R}$ absorbs the LowRate main effect: treatment status does not change within-region once the experiment starts. $\mathrm{T}$ is a vector of month-year dummies (e.g., separate dummies for June 2007 and June 2009), and these absorb the Post main effect. $\varepsilon$ is the error term. Throughout the paper we cluster standard errors at the unit of randomization, i.e., the region.

For most outcomes we lack more than two months of pre-treatment data, so the region fixed effects are not necessarily well-identified. Hence we also estimate: 
(2) $Y_{\mathrm{rt}}=\alpha+\beta^{2}\left({\left.\text { Low } \text { Rate }_{\mathrm{r}}^{*} \text { Post }_{\mathrm{t}}\right)+\lambda \text { LowRate }_{\mathrm{r}}+\tau T+\varepsilon}\right.$

The only change from (1) is that we replace the region fixed effects with the LowRate dummy.

Our third specification uses only post-treatment observations, but controls flexibly for pre-treatment outcomes:

(3) $Y_{\mathrm{rt}}=\alpha+\beta^{3}\left(\right.$ Low Rate $\left._{\mathrm{r}}\right)+\psi \mathrm{Y}_{\mathrm{r}}^{\mathrm{p}}+\tau \mathrm{T}+\varepsilon$

Here $\beta^{3}$ is the coefficient of interest, and $\mathrm{Y}^{\mathrm{p}}$ is a vector of variables, one for each pre-treatment observation. E.g., for loans disbursed, we have two months of pretreatment data for each region. So for each post-treatment observation (i.e, for each $\left.Y_{\mathrm{rt}}\right), \mathrm{Y}^{\mathrm{p}}$ is comprised of the same two variables and values for that region $\mathrm{r}$ : loans disbursed in March 2007, and loans disbursed in April 2007.

The price elasticity of demand is defined as the percentage change in quantity demanded divided by the percentage change in price. We calculate the former, for each specification, by dividing the coefficient of interest by the mean of $Y_{\mathrm{rt}}$ across all high-rate (control-group) regions, over the entire post-treatment period. We calculate the latter, again over the entire post-treatment period, by dividing the average, balance-weighted APR difference between high- and low-rate regions, and then dividing that difference by the average, balance-weighted APR in highrate regions.

As noted at the outset, we are able to identify price elasticities of demand under the assumption of no impact on supply-side decisions as a result of treatment. For example, it must be the case that the 20pp interest rate cut does not induce differential screening or monitoring than the 10pp rate cut. Our finding that delinquencies are not affected by the interest rate (see below) supports this assumption. It must also be the case that treatment and control regions did not 
receive different marketing (if marketing affects demand); this assumption seems reasonable given the study protocols (no operational changes other than price), and the fact that both treatment and control regions experienced rate cuts relative to Compartamos' prior rates. ${ }^{16}$

Table 3 presents results on the price sensitivity of loans taken out for each of specifications (1), (2), and (3). In each case the variable of interest shows a statistically significant increase of 190 to 200 loans disbursed per month in the low-rate regions, compared to the high rate regions. The implied elasticities (shown near the bottom of the table) are -1.3 or -1.4 .

Table 3 Columns 4-6 show that interest rate sensitivity increases over time, parameterized categorically (year-to-year). For this analysis we replace the variable estimating a single treatment effect with three interaction terms, one each for months 1-12, 13-24, and 25-29 post-treatment (with no omitted category, so each interaction identifies the price response for its time window). We see treatment effects rising from one year to the next (and cannot reject linearity) in level terms. The table also reports p-values showing that these effects are significantly different from year-to-year. The elasticities increase as well: from about -0.8 in year one to -1.5 in year two to -2.2 in year three. The finding that elasticities increase over time is consistent with borrower learning and/or adjustment costs. Appendix table 1 finds lower point elasticities using log of quantity of loans disbursed instead of the levels used in Table 3; e.g., -1.2 in the full sample, and -1.75 in year three. The results using logs are also less precise.

${ }^{16}$ For example, suppose that any substantial price change triggers informative advertising. In that case both our treatment and control regions would get the additional advertising, because both sets of regions got price cuts relative to Compartamos' prior rates. 


\section{Do Lower Rates Improve "Outreach”?}

Next we explore whether the lower interest rate increased take-up by groups that are often the focus of "outreach" intended to expand access to microcredit: new borrowers (Table 4a), those with less education (Table 4b), and the (relatively) poor (Table 4c). ${ }^{17}$ We re-estimate the specifications used in Table 3, with loans disbursed to one of the three groups as the dependent variable.

The results for new borrowers over the full study period (Table 4a Columns 13) show positive point estimates on the interest rate variables of interest that imply point elasticities in the -0.9 to -1.3 range. But the results are a bit imprecise, with $\mathrm{p}$-values ranging from 0.13 to 0.27 . Further down the table we report $\mathrm{p}$ values for tests of whether interest rate sensitivity is significantly different for new versus retained clients: it is not, although two of the p-values are 0.13 and 0.15 . Columns 4-6 show some evidence that new-client elasticities increase over time, as in the full sample (Table 3). These columns suggest new borrowers become increasingly responsive to the lower rate over time: the year 3 treatment effect is significant with $90 \%$ confidence in each specification, and significantly different than the other years' treatment effects. The Year 3 treatment effect implies an elasticity of new borrowers with respect to price of between -1.7 and 2.0 depending on specification. These columns also show that, by Year 3, interest rate sensitivity is significantly different for new versus retained clients. New clients are less sensitive (although only slightly so in elasticity units); we do not actually show the magnitude of the difference in the table to conserve space, but

\footnotetext{
${ }^{17}$ Recapping our definitions from Section III-A and Tables 1 and 2: in a given month, we define a loan to a new borrower as one disbursed to someone who had not borrowed from Compartamos in any previous month. We measure educational attainment for each borrower using Compartamos application data. We measure poverty likelihood for each borrower using application data that Compartamos starting collecting in June 2007. The poverty score formula is from Schreiner (2006).
} 
show the comparable results for retained clients in Appendix table 2 for comparison.

Table $4 \mathrm{~b}$ shows a similar pattern of results, with slightly lower but still elastic point elasticities, for lower-education borrowers. Columns 1-3 suggest unit elasticity on average for this group. Columns 4-6 show statistically significant year 3 elasticities of about -1.7 . We do not find significantly different price sensitivities for lower-education versus higher-education borrowers, although Appendix table 3 shows that the point elasticities are much larger in absolute value for the higher-education group.

Table 4c shows a limited set of results for loans disbursed to relatively poor borrowers: those with poverty likelihood $>=50 \%$. We lack pre-treatment data on poverty likelihood, so we can only estimate a version of equation (3) that does not control for pre-treatment outcomes. Column 1 shows an imprecisely estimated unit elasticity. Column 2 shows higher but imprecisely estimated point elasticities in years 2 and 3 than in year 1. We do not find significant differences in price sensitivity between low- and high-income borrowers, although Appendix table 4 shows that the point elasticities are much larger in absolute value for the higherincome group.

\section{Full Sample Results on Elasticities of Amount Borrowed from Compartamos}

Table 5 presents estimates of price sensitivities of the amount lent by (borrowed from) Compartamos, again measured as region-month flows. This measure of demand combines the extensive and intensive margins.

Columns 1-3 show a similar overall response to what we found for loans disbursed in Table 3. Each specification shows a statistically significant increase 
of about two million pesos per month in lower-rate compared to higher-rate regions. Point elasticities are in the -1.85 to -1.91 range. Columns $4-6$ estimate separate treatment effects and elasticities for each year post-treatment, and again show that price sensitivity increases over time: each of the yearly treatment effects are significantly different from each other. Each of the nine yearly elasticities is also significantly different from zero with at least $95 \%$ confidence. The Year 1 elasticities range from -1.09 to -1.18 . The Year 2 elasticities range from -1.93 to -1.99 . The Year 3 elasticities range from -2.86 to -2.91 .

Appendix table 5 estimates the same specifications with $\log (\operatorname{loan}$ amount) instead of level. The point elasticities are somewhat lower (about -1.7 in the full sample, and -2.4 in year three), and less precisely estimated.

\section{E. Rate Cuts in Equilibrium: Evidence on Net Elasticities from Credit Bureaus}

Credit bureau data enable us to examine another important aspect of general equilibrium responses to interest rate changes (besides the time-varying elasticities estimated in Tables 3-5): net elasticities that take into account any crowd-out or crowd-in of credit from other lenders. We have data from two bureaus: the Mexican Official Credit Bureau and the Circulo. Both bureaus allow us to focus only on loans that are comparable to Compartamos' loans. ${ }^{18}$ The Official Bureau has more comprehensive coverage (compare the means in Column 1 and 2 in Table 6), but has the disadvantage of including Compartamos loans in the region-level data we were able to obtain. ${ }^{19}$ The Circulo Bureau has the

\footnotetext{
${ }^{18}$ We include the following lending institution types: Bank, Bank loan PFAE, Credit line from bank, Non bank loan for PFAE, Financial non-bank loan for PFAE, Personal finance company, Medium market commerice, Medium market NF service, and Credit Union.

19 The credit bureaus would only provide us with data at the level of the municipality*lending institution type. So we cannot identify individual lenders or
} 
advantages of including Azteca, a main competitor of Compartamos, and of excluding Compartamos loans. ${ }^{20}$

The bureau data (Table 6) has three main differences from the Compartamos data used to estimate our main results on elasticities of demand for Compartamos debt (Tables 3-5). First, we were only able to obtain two snapshots from the bureaus: April 2007 (one month before the start of the pricing experiment), and December 2008. In all we have data from 79 regions at both points in time, for a total of 158 region-month observations. As such, Table 6 reports estimates from equation (2) only. Second, the Official Bureau data lacks loan amounts and the number of borrowers, so our main measure of aggregate demand is the number of loans. Third, the credit bureau captures stocks, not flows. Given these differences, Table 6 Column 3 also reports a comparable estimate for the stock of Compartamos loans measured from Compartamos' data, using the same two months (April 2007 and December 2008), and the same specification. There is a marginally significant treatment effect of about 800 loans in the Compartamos data, with an implied elasticity of -1.6.

The main inference we can make from the credit bureau data is a lack of strong evidence for crowd-out. Focusing on the Circulo (column 1), because this excludes Compartamos loans, we see a positive point estimate on Post*InterestRate, with a p-value of 0.16 , suggesting that crowd-in is more likely than crowd-out (Angelucci et al 2013 also finds some evidence that Compartamos lending increases generate crowd-in). Column 2 (from the Official Bureau) also

borrowers. To aggregate to regions we exclude the $3 \%$ of municipalities that straddle our regional boundaries, and the $16.5 \%$ of municipalities with $<20$ Compartamos clients. The latter exclusion improves power by focusing on the parts of regions where Compartamos actually has a presence (regions are large enough that Compartamos does not necessarily operate throughout the entire region).

${ }^{20}$ Another difference between the two credit bureaus is that the Circulo enables us to filter on loan type rather than lender type: we count only "Personal Loans". 
shows a large, positive point estimate that is much larger than the direct effect on Compartamos borrowing (compare to Column 3), but this point estimate is imprecisely estimated as well (p-value 0.2).

\section{F. Does Delinquency Fall with Price?}

We now turn to an analysis of whether the lower interest rate was profitable for Compartamos, starting with an examination of whether the lower rate affected loan delinquency (Table 7). As widely theorized, and tested experimentally in Karlan and Zinman (2009), interest rates can have a causal effect on loan repayments through multiple channels: asymmetric information (adverse selection and/or moral hazard), and/or an income effect under liquidity constraints. We also examine whether interest rates have delinquency effects that vary with measures of the prevalence of new borrowers in a region-month, under the hypothesis that any asymmetric information problem may be relatively severe for borrowers who have not contracted with Compartamos before. Our outcome of interest here is the proportion of groups, in a region-month, that are behind on their repayments. (Appendix table 6 reports estimates where the unit of observation is the groupmonth instead of the region-month. We find similar results.)

Our empirical models and sample are the same as for demand estimation, with three exceptions. First, Compartamos did not track delinquency systematically prior to the experiment, so we lack pre-treatment data and the ability to estimate equations (1) and (2). Instead, our estimator here is equation (3) sans the controls for pre-treatment outcomes. Second, we count only groups that could possibly be late in the denominator; i.e., we exclude groups that are too new to be delinquent. For the serious delinquency measure this excludes 163 region-months that are 
comprised entirely of groups with loans disbursed in the previous four months. Third, we omit specifications that allow for time-varying effects. ${ }^{21}$

Table 7 Columns 1-3 examine moderate delinquency--any lateness - and show little evidence of price response. The point estimates are all negative, however (consistent with lower rates mitigating asymmetric information), and the confidence intervals do not rule out economically meaningful effect sizes relative to the base rates at the region-month level, which are 0.14 for all groups, 0.15 for groups with $>75 \%$ new members, and 0.19 for new groups. Columns 4-6 show a similar pattern of results for severe delinquency: $>90$ days. Again the point estimates are all negative, with confidence intervals that contain large effects relative to the base rates of 0.10 to 0.16 .

\section{G. Rate Cuts in Equilibrium: Are They Profitable/Sustainable for Compartamos?}

Another key question for equilibrium is whether the lower interest rate was profitable, or at least sustainable, for Compartamos. Table 8 reports estimates, using equation (3), of how the lower interest rates affected Compartamos' interest income, costs, and profits. Appendix table 7 shows that we find similar results from our other two specifications.

Table 8 Column 1 shows an imprecisely estimated increase in interest income over the entire post-treatment period (note that any effect on delinquencies is nested here). The point estimates in Column 2 suggest that the effect on income increases over time.

${ }^{21}$ Results available upon request; we find no evidence of time-varying effects. 
Columns 3 and 4 of Table 8 show a similar but more precisely estimated pattern for total operating costs (note that any effect on chargeoffs is nested here). The point estimates are all positive- the lower interest rate increases costs as well as revenues - and a bit smaller than the point estimates for revenues. Appendix table 8 suggests that about half of the cost increase is due to personnel. Appendix table 9 shows that costs fall in the average number of members per group, and increase with the number of groups. Appendix table 10 shows some evidence that lower rate regions increase groups and group size (Column 1-4), but that loan officers do not handle significantly more groups or clients. In all, we find little evidence of economies of scale given current operations and firm structure. Innovations with respect to lending technology, such as mobile devices with customized software for credit officers (that are being implemented by many lenders, including Compartamos), may help lower marginal costs and capture economies of scale in the future.

Table 8 Columns 5 and 6 show null effects on profits (unsurprising given the previous columns, and note that the treatment effects do not add up perfectly due to the inclusion of control variables). The year-three point estimates hint the lower rate might be profitable in the (very) long-run, as the elasticity increases over time. But the confidence intervals also include large negative effects on profits: the results are imprecise.

So why had not Compartamos cut interest rates earlier? After all, given profitneutrality, elastic demand, and a "double bottom line" of helping clients to "generate social and economic value", as well as the possibility of increased cross-sells, the lower rate interest has turned out to be beneficial for Compartamos ex-post. We speculate that costly experimentation may discourage some lenders from deriving their demand curves. In addition to direct costs, there may be a risk to cutting rates if demand curves develop kinks at current market rates that make 
subsequent increases quite costly. ${ }^{22}$ We discuss some implications of costly experimentation for market equilibria and future research in the Conclusion.

\section{H. Rate Cuts in Equilibrium: Evidence on Competitors' (Non-)Responses}

Our last bit of evidence on the general equilibrium effects of Compartamos' pricing changes comes from some standard market research on competitors' offerings. We worked with Compartamos' senior management to lay out some simple protocols for the bank's field staff to gather data on interest rates and loan terms: 1) collect data for at least the three top competitors in each region; 2) collect data by having someone pose as a prospective client seeking a 4,000 peso loan (a typical loan size for a new microcredit client); 3) collect data at two points in time, first in May 2007 (just prior to the start of the study), and then one at least one year after the start of the experiment (although some branch managers reported back as early as April 2008); 4) collect data on the same competitors in the pre- and post-periods, and also on new competitors in the post-period as merited by any changes in the competitive environment. 19 of 73 regions reporting in both periods reported a constant set of competitors. ${ }^{23}$ The number of competitors ranged from 1 to 10 , with a mean of 3.12 .

Table 9 presents estimates of whether and how competitors respond to Compartamos' lower interest rate. Given only two observations per region, we

\footnotetext{
${ }^{22}$ Karlan and Zinman (2008) finds extremely elastic demand to rates increases but not decreases, an asymmetry the lender there had anticipated.

${ }^{23}$ Two regions did not provide post-treatment competitor rates, three regions did not provide pre-treatment competitor rates, and two regions did not have any branches operating in the pre-treatment period.
} 
estimate equation (2), in some cases adding controls for maturity (a cubic, in weeks). In Columns 1-8 the dependent variable is equal to the average or lowest competitor APR in the region. We vary whether we use the full sample of 152 competitor pricing observations, restrict the sample to competitors captured in both the baseline and follow-up (this drops 10 of the 152 observations), or further restrict to competitors with the same loan maturity in both baseline and follow-up (this drops 54 of the 152 observations).

The results paint the same picture regardless of specification: all eight estimates for the effect of Post ${ }^{*}$ LowRate on competitor APRs are positive, suggesting that if anything competitors respond to Compartamos' lower rate by raising prices. We also test the hypothesis that competitors match Compartamos' lower rate (i.e., that Post ${ }^{*}$ LowRate $=-10$ ), and we reject that hypothesis with $90 \%$ confidence in five out of the eight specifications ( $p$-values reported in the bottom row of the table). We do not find any effects on competitor counts either (Columns 9 and 10).

Why don't competitors follow Compartamos' rate cut if demand is elastic? The simplest answer is that it would not change profits (it did not for Compartamos: recall Table 8). And if our inference from the credit bureau data is correct-no crowd-out of borrowing from competitors (crowd-in if anything) - then competitors did not feel the consequences of Compartamos' lower rates on their own revenues, either.

Why don't borrowers substitute away from competitors (again recall the lack of crowd-out in Table 6) if Compartamos offers lower prices and the competitors do not? One possibility is product differentiation. Another is search and/or switch costs. Yet another is liquidity constraints: if borrowers had excess demand at pretreatment market rates, they might borrow more on the margin, from 
Compartamos, without reducing their inframarginal borrowing. Crowd-in can result if there are both liquidity constraints and non-convexities in investment Banerjee and Newman (1993).

\section{Conclusion}

We study the long-run (up to 29-month) effects of a $10 \%$ interest rate reduction by the largest microlender in Mexico, using a field experiment implemented at the level of 80 distinct geographic regions. Demand for Compartamos loans is quite elastic, and gets more so over time. For example, the average elasticity of amount borrowed over the 29 months is about -1.9 , with a year one elasticity of about -1.1, and a year three (month 25-29) elasticity of about -2.9. There is no strong evidence of crowd-out in credit bureau data. The lower rate is profit-neutral for Compartamos, and the bank has maintained the lower rate post-experiment, confirming that the lower rate has been sustainable for Compartamos. We find no evidence that competitors responded by cutting rates.

These findings suggest several avenues for future research. First, understanding why elasticities grow over time-e.g., the relative importance of learning versus adjustment costs-is important for modeling and policy analysis. A closely related line of inquiry would unpack relationships between elasticities of demand for credit and for saving. Estimates of the elasticities of demand for savings range as low as zero (Hall 1988; Karlan and Zinman 2012), and most are strictly below the elasticities we find here.

There is also much to learn about microlending production functions as well. Our results suggest an absence of commonly-assumed economies of scale, and it would be useful to know what prevents Compartamos (and, presumably, other microlenders) from capturing scale economies. Is it something inherent to the 
group lending model? Labor market frictions? A longer transition path to scale economies than our study window; i.e., perhaps it takes time to re-optimize fixed costs to handle the increased loan volume?

Obtaining more precise estimates of aggregate credit demand and net elasticities is also important. Our finding of no crowd-out even though competitors do not price-match raises possibilities that switch costs have big effects on market outcomes, and/or that liquidity constraints work in surprising ways: the standard story is that liquidity constraints make agents price-inelastic, but perhaps this is true only of responses to price increases.

The possibility of asymmetric responses to price increases and decreases raises another possibility that fits with our results: multiple equilibria borne of costly experimentation along the profit-maximizing frontier. Holding profits constant (as turned out to the case in our experiment), a lower interest rate would seem to be at least weakly better for a lender like Compartamos, since the lower rate delivers social benefits from the largely beneficial average impacts of increased access to microcredit (Angelucci, Karlan, and Zinman 2013), in addition to public relations benefits and increased opportunities for cross-sells. So a natural follow-on question is why firms (including Compartamos) do not charge lower rates to begin with. One possibility worth exploring is that experimenting with lower rates is risky: a lower rate may reset customer expectations of a fair/market rate, and create a kink in the demand curve. Karlan and Zinman (2008) find evidence along these lines in South Africa. If this dynamic holds, then cutting rates may reduce or eliminate the option to increase rates in the future (e.g., if it turns out that the lower rate was not as profitable as the initial rate). In this case policymakers might consider interventions to spur learning about pricing. 


\section{References}

Alessie, R., S. Hochguertel, and G. Weber. 2005. "Consumer Credit: Evidence from Italian Micro Data." Journal of the European Economic Association 3 (1): 144-78.

Angelucci, Manuela, Dean Karlan, and Jonathan Zinman. 2013. "Win Some Lose Some? Evidence from a Randomized Microcredit Program Placement Experiment by Compartamos Banco." Working Paper.

Armendariz de Aghion, Beatriz, and Jonathan Morduch. 2010. The Economics of Microfinance. 2nd ed. Cambridge, MA: MIT Press.

Attanasio, Orazio, Pinelope Goldberg, and Ekaterini Kyriazidou. 2008. "Credit Constraints In The Market For Consumer Durables: Evidence From Micro Data On Car Loans." International Economic Review 49 (2). International Economic Review: 401-436.

Attanasio, Orazio, and Guglielmo Weber. 2010. "Consumption and Saving: Models of Intertemporal Allocation and Their Implications for Public Policy." Journal of Economic Literature 48 (3): 693-751.

Ausubel, Lawrence M. 1999. "Adverse Selection in the Credit Card Market." Mimeo, University of Maryland.

Banerjee, Abhijit, and Andrew Newman. 1993. "Occupational Choice and the Process of Development." Journal of Political Economy 101: 274-298.

Bengtsson, Niklas, and Jan Pettersson. 2012. "The Outreach and Sustainability of Microfnance: Is There a Tradeoff?" Working Paper.

Dehejia, Rajeev, Heather Montgomery, and Jonathan Morduch. 2012. "Do Interest Rates Matter? Credit Demand in the Dhaka Slums." Journal of Development Economics 97 (2): 437-449.

Gross, David B, and Nicholas S Souleles. 2002. "Do Liquidity Constraints and Interest Rates Matter for Consumer Behavior? Evidence from Credit Card Data." The Quarterly Journal of Economics 117 (1): 149-85.

Hall, Robert E. 1988. "Intertemporal Substitution in Consumption." Journal of Political Economy 96: 339-57.

Karlan, Dean, and Jonathan Morduch. 2009. “Access to Finance." In Handbook of Development Economics. Vol. 5. Edited by Dani Rodrik Mark Rosenzweig. Elsevier.

Karlan, Dean, and Jonathan Zinman. 2008. "Credit Elasticities in Less Developed Economies: Implications for Microfinance." American Economic Review $98(3)$.

2009. "Observing Unobservables: Identifying Information Asymmetries with a Consumer Credit Field Experiment." Econometrica 77 (6): 19932008. 
_. 2013. "Price and Control Elasticities of Demand for Savings." Working Paper.

Rosenberg, Richard. 2002. "Microcredit Interest Rates." Consultative Group to Assist the Poor Occasional Paper (1) (November).

Schreiner, Mark. 2006. "Seven Simple Poverty Scorecards." 
Table 1. Baseline Summary Statistics and Orthogonality Means and Standard Errors

\begin{tabular}{|c|c|c|c|}
\hline & $\begin{array}{c}\text { Low rate } \\
\text { (1) }\end{array}$ & $\begin{array}{l}\text { High Rate } \\
\text { (2) }\end{array}$ & $\begin{array}{c}\text { Difference in Means } \\
(1)-(2) \\
(3)\end{array}$ \\
\hline \multicolumn{4}{|l|}{ Panel A: Borrower characteristics } \\
\hline Proportion of clients with high school or more & $\begin{array}{c}0.503 \\
(0.025)\end{array}$ & $\begin{array}{c}0.457 \\
(0.023)\end{array}$ & $\begin{array}{c}0.046 \\
(0.034)\end{array}$ \\
\hline Age & $\begin{array}{l}40.222 \\
(0.226)\end{array}$ & $\begin{array}{l}40.191 \\
(0.235)\end{array}$ & $\begin{array}{c}0.031 \\
(0.326)\end{array}$ \\
\hline Number of children & $\begin{array}{c}3.072 \\
(0.063)\end{array}$ & $\begin{array}{c}3.183 \\
(0.064)\end{array}$ & $\begin{array}{l}-0.111 \\
(0.089)\end{array}$ \\
\hline Number of dependents & $\begin{array}{c}1.986 \\
(0.037)\end{array}$ & $\begin{array}{c}1.970 \\
(0.052)\end{array}$ & $\begin{array}{c}0.015 \\
(0.064)\end{array}$ \\
\hline Number of married clients & $\begin{array}{l}510.718 \\
(63.465)\end{array}$ & $\begin{array}{l}518.179 \\
(47.453)\end{array}$ & $\begin{array}{c}-7.462 \\
(79.244)\end{array}$ \\
\hline \multicolumn{4}{|l|}{ Panel B: Loan volume } \\
\hline Number of clients borrowing this month & $\begin{array}{l}858.179 \\
(99.863)\end{array}$ & $\begin{array}{l}821.385 \\
(69.634)\end{array}$ & $\begin{array}{c}36.795 \\
(121.744)\end{array}$ \\
\hline Number of loans & $\begin{array}{l}858.179 \\
(99.863)\end{array}$ & $\begin{array}{l}821.385 \\
(69.634)\end{array}$ & $\begin{array}{c}36.795 \\
(121.744)\end{array}$ \\
\hline Number of outstanding loans & $\begin{array}{l}2,925.333 \\
(359.782)\end{array}$ & $\begin{array}{l}2,826.564 \\
(249.812)\end{array}$ & $\begin{array}{c}98.769 \\
(438.006)\end{array}$ \\
\hline Number of new clients borrowing this month & $\begin{array}{c}192.231 \\
(19.161)\end{array}$ & $\begin{array}{l}155.744 \\
(10.935)\end{array}$ & $\begin{array}{c}36.487 \\
(22.062)\end{array}$ \\
\hline Number of retained clients borrowing this month & $\begin{array}{l}665.949 \\
(87.198)\end{array}$ & $\begin{array}{l}665.641 \\
(62.002)\end{array}$ & $\begin{array}{c}0.308 \\
(106.994)\end{array}$ \\
\hline Number of outstanding loans of retained clients & $\begin{array}{l}2,337.769 \\
(324.065)\end{array}$ & $\begin{array}{l}2,341.615 \\
(228.227)\end{array}$ & $\begin{array}{c}-3.846 \\
(396.366)\end{array}$ \\
\hline Number of clients with high school or more & $\begin{array}{l}395.179 \\
(47.786)\end{array}$ & $\begin{array}{l}353.077 \\
(31.846)\end{array}$ & $\begin{array}{c}42.103 \\
(57.425)\end{array}$ \\
\hline Number of clients without high school & $\begin{array}{l}462.051 \\
(61.725)\end{array}$ & $\begin{array}{l}467.923 \\
(45.506)\end{array}$ & $\begin{array}{c}-5.872 \\
(76.686)\end{array}$ \\
\hline Loan amount for all loans disbursed ( $\mathrm{M} \$$ thousands) & $\begin{array}{l}6,064.544 \\
(840.700) \\
\end{array}$ & $\begin{array}{l}5,924.230 \\
(638.784) \\
\end{array}$ & $\begin{array}{c}140.314 \\
(1055.851) \\
\end{array}$ \\
\hline $\mathrm{N}$ & 39 & 39 & 78 \\
\hline
\end{tabular}


Table 1(continued). Baseline Summary Statistics and Orthogonality Means and Standard Errors

\begin{tabular}{|c|c|c|c|}
\hline & $\begin{array}{l}\text { Low rate } \\
(1)\end{array}$ & $\begin{array}{l}\text { High Rate } \\
(2)\end{array}$ & $\begin{array}{l}\text { Difference in Means } \\
(1)-(2) \\
(3) \\
\end{array}$ \\
\hline \multicolumn{4}{|l|}{ Panel C: Loan characteristics } \\
\hline Loan amount (M\$ thousands) & $\begin{array}{c}6.464 \\
(0.250)\end{array}$ & $\begin{array}{c}6.468 \\
(0.277)\end{array}$ & $\begin{array}{l}-0.004 \\
(0.373)\end{array}$ \\
\hline Loan amount for loans disbursed to new clients & $\begin{array}{l}716.133 \\
(75.249)\end{array}$ & $\begin{array}{l}566.186 \\
(47.316)\end{array}$ & $\begin{array}{l}149.947 * \\
(88.889)\end{array}$ \\
\hline Loan amount for loans disbursed to retained clients & $\begin{array}{l}5,348.411 \\
(793.515)\end{array}$ & $\begin{array}{l}5,358.044 \\
(604.132)\end{array}$ & $\begin{array}{c}-9.633 \\
(997.317)\end{array}$ \\
\hline APR (including VAT, not including forced savings) & $\begin{array}{l}97.956 \\
(1.709)\end{array}$ & $\begin{array}{l}99.673 \\
(1.967)\end{array}$ & $\begin{array}{l}-1.717 \\
(2.606)\end{array}$ \\
\hline Number of of members in a group & $\begin{array}{l}16.771 \\
(0.282)\end{array}$ & $\begin{array}{l}16.774 \\
(0.281)\end{array}$ & $\begin{array}{l}-0.003 \\
(0.398)\end{array}$ \\
\hline Number of of groups & $\begin{array}{l}49.051 \\
(5.345) \\
\end{array}$ & $\begin{array}{l}48.000 \\
(3.966) \\
\end{array}$ & $\begin{array}{r}1.051 \\
(6.655) \\
\end{array}$ \\
\hline \multicolumn{4}{|l|}{ Panel D: Market Share Characteristics } \\
\hline Population Density in 2005 & $\begin{array}{c}288.128 \\
(271.248)\end{array}$ & $\begin{array}{c}121.176 \\
(113.140)\end{array}$ & $\begin{array}{c}166.952 \\
(293.899)\end{array}$ \\
\hline \multirow[t]{2}{*}{$\begin{array}{l}\text { Borrowers Per Capita: (Number of Compartamos Clients in April } \\
\text { 2007)/(Population as of } 2005 \text { Mexico Census) }\end{array}$} & 0.029 & 0.029 & -0.000 \\
\hline & $(0.002)$ & $(0.002)$ & $(0.003)$ \\
\hline \multirow[t]{2}{*}{$\begin{array}{l}\text { Market Proportion 1: (Number of Compartamos Clients in April } \\
\text { 2007) / (Number of Borrowers with Comparable Loans in Official } \\
\text { Credit Bureau Data in April 2007) }\end{array}$} & 0.154 & 0.157 & -0.003 \\
\hline & $(0.030)$ & $(0.026)$ & $(0.040)$ \\
\hline \multirow[t]{2}{*}{$\begin{array}{l}\text { Market Proportion 2: (Number of Compartamos Clients in April } \\
\text { 2007) / (Number of Borrowers with Comparable Loans Recorded in } \\
\text { Circulo Credit Bureau Data in April 2007) }\end{array}$} & 0.985 & 1.193 & -0.208 \\
\hline & $(0.144)$ & $(0.173)$ & $(0.225)$ \\
\hline \multirow{2}{*}{$\begin{array}{l}\text { Market Proportion 3: (Number of Compartamos Clients in April } \\
\text { 2007) / (Number of Borrowers with Comparable Loans Recorded in } \\
\text { Merged Credit Bureau Data in April 2007) }\end{array}$} & 0.126 & 0.137 & -0.011 \\
\hline & $(0.022)$ & $(0.023)$ & $(0.031)$ \\
\hline \multirow{2}{*}{$\begin{array}{l}\text { Market Proportion 4: (Compartamos Loan Balance in } \$ 1,000 \text { s in } \\
\text { April 2007) / (Comparable Loan Balance in Circulo Credit Bureau } \\
\text { Data in M\$ millions in April 2007) }\end{array}$} & 339.511 & 423.418 & -83.907 \\
\hline & $(54.178)$ & $(69.709)$ & (88.287) \\
\hline
\end{tabular}

$$
\mathrm{N}
$$$$
39
$$$$
39
$$

Unit of observation is the region for the time period of April, 2007. Regions are the unit of randomization and comprised of 1-4 bank branches. Of the eighty regions in our study, two were not open before the start of the treatment period, yielding a total of 78 regions included in the table. Standard errors in parentheses. Each client only have one loan at the time. New clients are defined as those who get their first loan ever in that month. Retained clients are defined as those who had already had a loan in previous months. Poverty likelihood variables and delinquency data is not available at baseline. Population estimates are derived from the 2005 Mexican Census. We define "comparable loans" in the Mexican Credit Bureau as loans from a Bank, Bank loan PFAE, Credit line from bank, Non bank loan for PFAE, Financial non-bank loan for PFAE, Personal finance company, Medium market commerice, Medium market NF service, or Credit Union. In the Circulo data, "comparable" loans are those which institutions choose to report as "personal loans". Compartamos loans are captured in the Mexican credit bureau, but not in the Circulo credit bureau. For credit bureau data, we only count loans from comparable lenders: Bank, Bank loan PFAE, Credit line from bank, Non bank loan for (PFAE), Financial non-bank loan for PFAE, Personal finance company, Medium market commerice, Medium market NF service, or Credit Union. All municipalities included in the credit bureau data have 20 or more Compartamos clients. * significant at $10 \%$; ** significant at $5 \% ; * * *$ significant at $1 \%$. 
Table 2. Simple Means Comparisons (Treatment - Control)

Differences and Standard Errors

\begin{tabular}{|c|c|c|c|c|c|c|}
\hline & $\begin{array}{c}\text { In } \\
\text { November } 2007 \\
\text { (1) }\end{array}$ & $\begin{array}{c}\text { In } \\
\text { May } 2008 \\
(2)\end{array}$ & $\begin{array}{c}\text { In } \\
\text { November } 2008 \\
\text { (3) }\end{array}$ & $\begin{array}{c}\text { In } \\
\text { May } 2009 \\
(4)\end{array}$ & $\begin{array}{c}\text { In } \\
\text { October } 2009 \\
(5)\end{array}$ & $\begin{array}{c}\text { Complete post } \\
\text { treatment period } \\
(6)\end{array}$ \\
\hline \multicolumn{7}{|l|}{ Panel A: Interest Rate, per region } \\
\hline APR on loans disbursed (balance-weighted) & $\begin{array}{c}-8.906^{* * *} \\
(0.648)\end{array}$ & $\begin{array}{c}-9.488^{* * *} \\
(0.662)\end{array}$ & $\begin{array}{c}-10.371^{* * *} \\
(0.647)\end{array}$ & $\begin{array}{c}-10.346^{* * *} \\
(0.661)\end{array}$ & $\begin{array}{c}-10.718^{* * *} \\
(0.624)\end{array}$ & $\begin{array}{c}-9.832^{* * *} \\
(0.535)\end{array}$ \\
\hline \multicolumn{7}{|l|}{ Panel B: Loans Disbursed, per region } \\
\hline \# of loans disbursed & $\begin{array}{c}91.250 \\
(162.048)\end{array}$ & $\begin{array}{c}175.625 \\
(150.950)\end{array}$ & $\begin{array}{c}137.750 \\
(182.210)\end{array}$ & $\begin{array}{c}338.250^{*} \\
(189.925)\end{array}$ & $\begin{array}{l}547.825^{\star *} \\
(268.420)\end{array}$ & $\begin{array}{c}236.843 \\
(177.563)\end{array}$ \\
\hline Point elasticity & -0.768 & -1.594 & -0.941 & -2.423 & -2.748 & -1.672 \\
\hline \# of loans disbursed to new clients & $\begin{array}{c}52.050 \\
(35.154)\end{array}$ & $\begin{array}{c}59.475 \\
(40.495)\end{array}$ & $\begin{array}{c}42.175 \\
(46.678)\end{array}$ & $\begin{array}{l}114.100^{* *} \\
(45.468)\end{array}$ & $\begin{array}{l}137.625^{* *} \\
(64.154)\end{array}$ & $\begin{array}{l}81.361^{* *} \\
(40.492)\end{array}$ \\
\hline Point elasticity & -1.929 & -2.119 & -1.110 & -3.264 & -2.857 & -2.373 \\
\hline \multirow[t]{2}{*}{$\begin{array}{l}\# \text { of loans disbursed to clients with poverty } \\
\text { likelihood }<50 \%\end{array}$} & 73.725 & 77.575 & 54.175 & 96.700 & 158.675 & 78.325 \\
\hline & $(114.468)$ & $(107.871)$ & $(124.477)$ & $(125.783)$ & $(162.128)$ & $(122.653)$ \\
\hline Point elasticity & -1.775 & -1.349 & -0.768 & -1.446 & -1.658 & -1.121 \\
\hline \multirow{2}{*}{$\begin{array}{l}\text { \# of loans disbursed to clients that have not } \\
\text { completed high school }\end{array}$} & 43.500 & 74.450 & 30.925 & 125.675 & 200.575 & 84.124 \\
\hline & $(99.627)$ & $(89.731)$ & $(100.580)$ & (106.095) & (137.185) & $(103.082)$ \\
\hline Point elasticity & -0.673 & -1.234 & -0.398 & -1.702 & -1.978 & -1.108 \\
\hline \multicolumn{7}{|l|}{ Panel C: Loan Amount $(1,000 \mathrm{~s}$, Pesos), per region } \\
\hline Loan amount for all loans disbursed & $\begin{array}{c}1,025.022 \\
(1,510.926)\end{array}$ & $\begin{array}{c}1,570.144 \\
(1,414.327)\end{array}$ & $\begin{array}{c}1,313.610 \\
(1,710.615)\end{array}$ & $\begin{array}{l}2,894.304^{*} \\
(1,708.442)\end{array}$ & $\begin{array}{l}5,206.458^{* *} \\
(2,413.994)\end{array}$ & $\begin{array}{c}2,148.340 \\
(1,641.733)\end{array}$ \\
\hline Point elasticity & -1.148 & -1.937 & -1.204 & -2.873 & -3.600 & -2.073 \\
\hline \multirow{2}{*}{ Loan amount for loans disbursed to new clients } & $267.426^{*}$ & $344.698^{*}$ & 208.117 & $519.000^{* *}$ & $653.706^{* *}$ & $396.197^{* *}$ \\
\hline & $(160.622)$ & $(185.945)$ & $(214.453)$ & $(205.120)$ & $(289.629)$ & $(185.806)$ \\
\hline Point elasticity & -2.519 & -3.177 & -1.340 & -3.647 & -3.250 & -2.875 \\
\hline \multirow[t]{2}{*}{$\begin{array}{l}\text { Loan amount for loans disbursed to clients with } \\
\text { poverty likelihood }<50 \%\end{array}$} & 993.061 & 942.817 & 907.769 & $1,175.228$ & $2,064.349$ & $1,061.817$ \\
\hline & $(982.579)$ & $(944.380)$ & $(1,054.986)$ & $(1,034.073)$ & $(1,365.948)$ & $(1,039.296)$ \\
\hline Point elasticity & -2.217 & -2.352 & -1.745 & -2.578 & -3.328 & -2.177 \\
\hline \multirow[t]{2}{*}{$\begin{array}{l}\text { Loan amount for loans disbursed to clients that } \\
\text { have not completed high school }\end{array}$} & 588.268 & 760.733 & 399.053 & $1,218.071$ & $2,086.077^{*}$ & 898.381 \\
\hline & $(889.024)$ & $(827.799)$ & $(902.403)$ & $(924.954)$ & $(1,218.710)$ & $(923.958)$ \\
\hline Point elasticity & -1.244 & -1.742 & -0.707 & -2.338 & -2.914 & -1.657 \\
\hline $\mathrm{N}$ & 80 & 80 & 80 & 80 & 80 & 80 \\
\hline
\end{tabular}

Continued on next page 
Table 2(continued): Simple Means Comparisons (Treatment - Control) Differences and Standard Errors

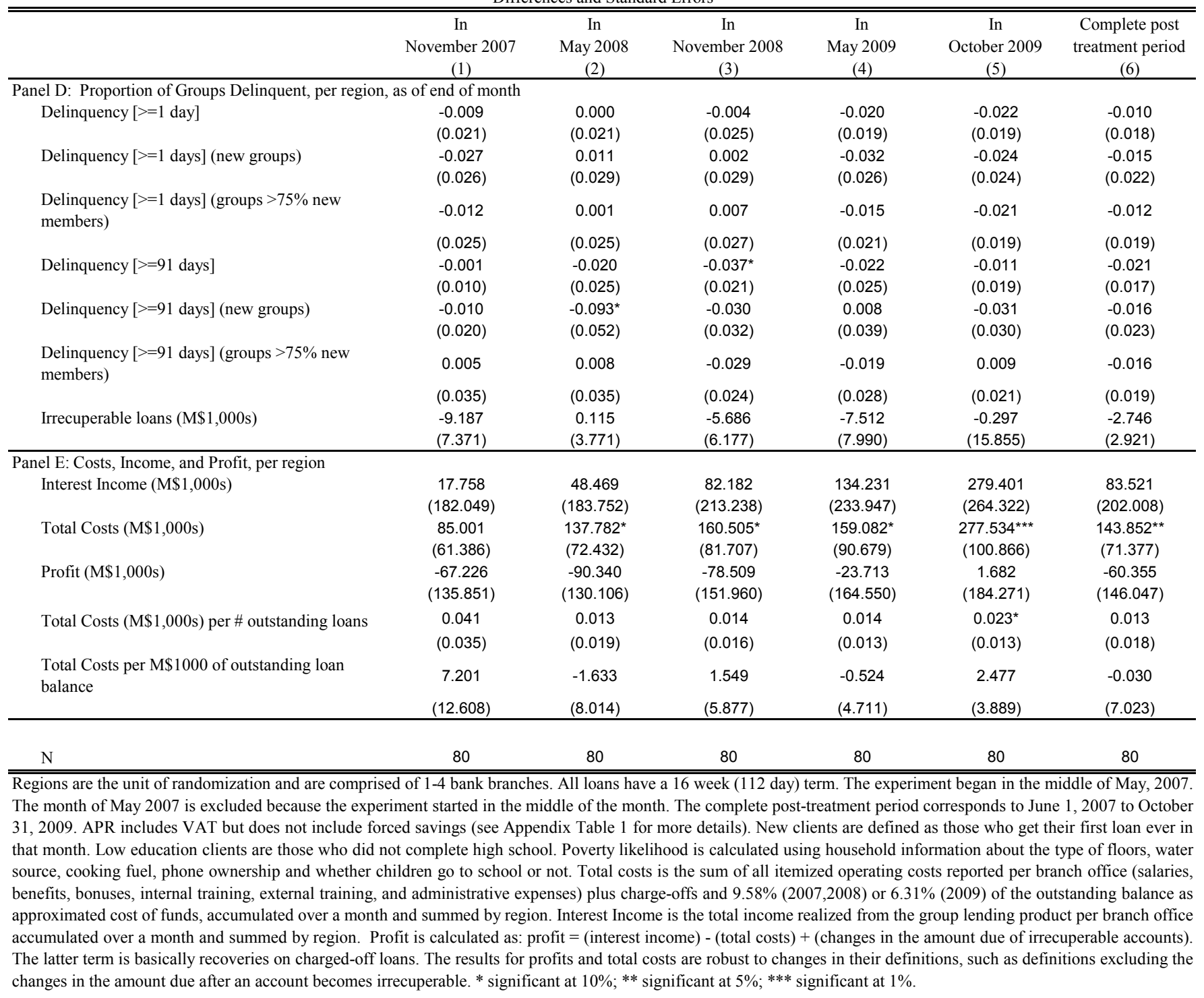




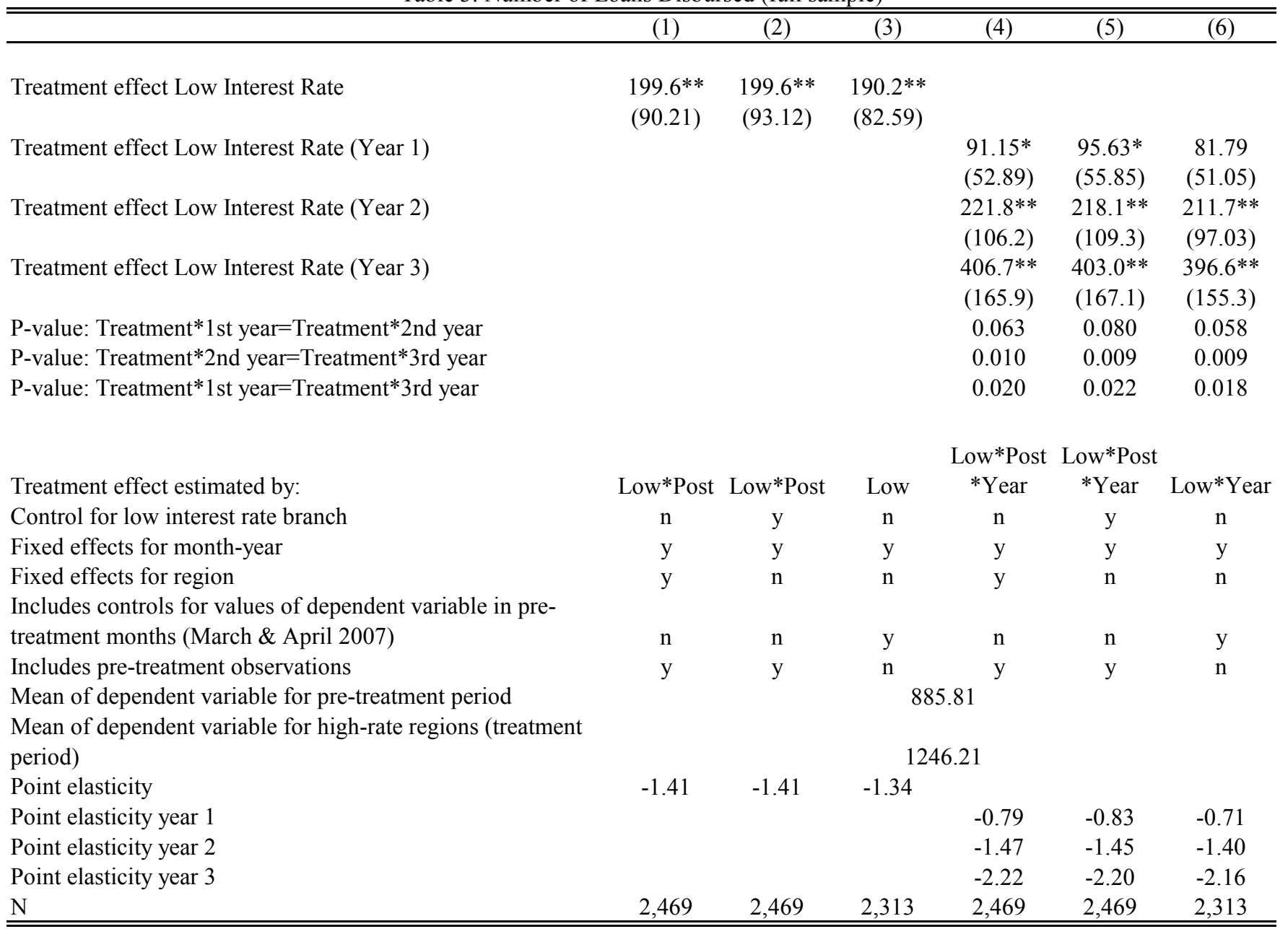

Each column reports results for an OLS regression of number of loans on the variables shown or summarized in the rows. Unit of observation is the region-month, and unit of randomization is the region, so standard errors allow for clustering at the region level. Treatment was implemented on May 16, 2007. The month of May 2007 is excluded because the experiment started in the middle of the month. Post $=1$ for the time period of June 1, 2007 to October 31, 2009. Pre-treatment months are March and April 2007. * significant at $10 \% ; * *$ significant at $5 \% ; * * *$ significant at $1 \%$. 


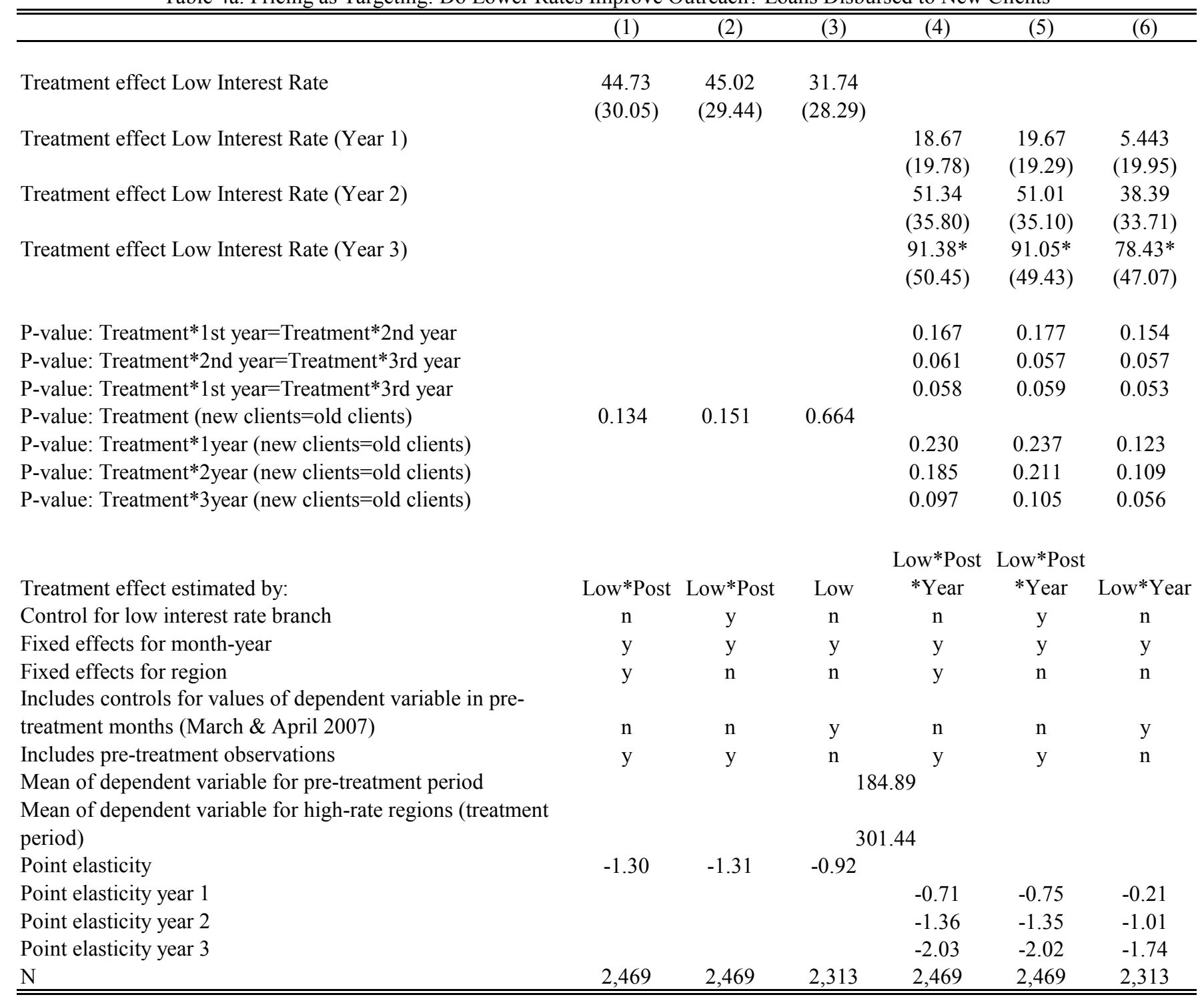

Each column reports results for an OLS regression of number of loans for new clients on the variables shown or summarized in the rows. Unit of observation is the region-month, and unit of randomization is the region, so standard errors allow for clustering at the region level. Treatment was implemented on May 16, 2007. The month of May 2007 is excluded because the experiment started in the middle of the month. Post $=1$ for the time period of June 1, 2007 to October 31, 2009. Pre-treatment months are March and April 2007. New clients are defined as those who get their first loan ever in that month. * significant at $10 \%$; ** significant at $5 \%$; *** significant at $1 \%$. 


\begin{tabular}{|c|c|c|c|c|c|c|}
\hline & $(1)$ & $(2)$ & (3) & $(4)$ & $(5)$ & $(6)$ \\
\hline Treatment effect Low Interest Rate & $\begin{array}{c}75.07 \\
(46.19)\end{array}$ & $\begin{array}{c}75.42 \\
(47.84)\end{array}$ & $\begin{array}{l}81.68 * \\
(44.70)\end{array}$ & & & \\
\hline Treatment effect Low Interest Rate (Year 1) & & & & $\begin{array}{c}40.46 \\
(30.53)\end{array}$ & $\begin{array}{l}43.10 \\
(31.96)\end{array}$ & $\begin{array}{c}47.20 \\
(30.70)\end{array}$ \\
\hline Treatment effect Low Interest Rate (Year 2) & & & & $\begin{array}{c}78.75 \\
(54.21)\end{array}$ & $\begin{array}{c}77.32 \\
(56.13)\end{array}$ & $\begin{array}{l}85.08 \\
(52.25)\end{array}$ \\
\hline Treatment effect Low Interest Rate (Year 3) & & & & $\begin{array}{l}149.3^{*} \\
(77.76)\end{array}$ & $\begin{array}{l}147.9 * \\
(78.49)\end{array}$ & $\begin{array}{l}155.6^{* *} \\
(74.73)\end{array}$ \\
\hline P-value: Treatment $* 1$ st year $=$ Treatment $* 2$ nd year & & & & 0.262 & 0.317 & 0.256 \\
\hline P-value: Treatment $* 2$ nd year $=$ Treatment $* 3 \mathrm{rd}$ year & & & & 0.021 & 0.019 & 0.019 \\
\hline P-value: Treatment* 1 st year $=$ Treatment $* 3 \mathrm{rd}$ year & & & & 0.068 & 0.077 & 0.064 \\
\hline P-value: Treatment (high educ $=$ low educ) & 0.473 & 0.488 & 0.731 & & & \\
\hline P-value: Treatment*1year (high educ $=$ low educ) & & & & 0.797 & 0.820 & 0.672 \\
\hline P-value: Treatment $* 2$ year (high educ $=$ low educ) & & & & 0.432 & 0.454 & 0.627 \\
\hline P-value: Treatment*3year (high educ=low educ) & & & & 0.394 & 0.398 & 0.494 \\
\hline Treatment effect estimated by: & Low*Post & Low*Post & Low & $\begin{array}{l}\text { Low*Post } \\
\quad * \text { Year }\end{array}$ & $\begin{array}{l}\text { Low*Post } \\
\quad * \text { Year }\end{array}$ & Low*Year \\
\hline Control for low interest rate branch & $\mathrm{n}$ & $\mathrm{y}$ & $\mathrm{n}$ & $\mathrm{n}$ & $\mathrm{y}$ & $\mathrm{n}$ \\
\hline Fixed effects for month-year & $\mathrm{y}$ & $\mathrm{y}$ & $\mathrm{y}$ & $\mathrm{y}$ & $\mathrm{y}$ & $\mathrm{y}$ \\
\hline Fixed effects for region & $\mathrm{y}$ & $\mathrm{n}$ & $\mathrm{n}$ & $\mathrm{y}$ & $\mathrm{n}$ & $\mathrm{n}$ \\
\hline $\begin{array}{l}\text { Includes controls for values of dependent variable in pre- } \\
\text { treatment months (March \& April 2007) }\end{array}$ & $\mathrm{n}$ & $\mathrm{n}$ & $\mathrm{y}$ & $\mathrm{n}$ & $\mathrm{n}$ & $\mathrm{y}$ \\
\hline Includes pre-treatment observations & $\mathrm{y}$ & $\mathrm{y}$ & $\mathrm{n}$ & $\mathrm{y}$ & $\mathrm{y}$ & $\mathrm{n}$ \\
\hline Mean of dependent variable for pre-treatment period & \multicolumn{6}{|c|}{494.57} \\
\hline $\begin{array}{l}\text { Mean of dependent variable for high-rate regions (treatment } \\
\text { period) }\end{array}$ & \multicolumn{6}{|c|}{667.87} \\
\hline Point elasticity & -0.99 & -0.99 & -1.08 & & & \\
\hline Point elasticity year 1 & & & & -0.79 & -0.84 & -0.92 \\
\hline Point elasticity year 2 & & & & -1.12 & -1.10 & -1.21 \\
\hline Point elasticity year 3 & & & & -1.67 & -1.66 & -1.74 \\
\hline $\mathrm{N}$ & 2,469 & 2,469 & 2,313 & 2,469 & 2,469 & 2,313 \\
\hline
\end{tabular}

Each column reports results for an OLS regression of number of loans for clients with low education on the variables shown or summarized in the rows. Unit of observation is the region-month, and unit of randomization is the region, so standard errors allow for clustering at the region level. Treatment was implemented on May 16, 2007. The month of May 2007 is excluded because the experiment started in the middle of the month. Post $=1$ for the time period of June 1, 2007 to October 31, 2009. Pre-treatment months are March and April 2007. Clients with low education are defined as those who did not complete high school. * significant at $10 \% ; * *$ significant at $5 \% ; * * *$ significant at $1 \%$. 
Table 4c. Pricing as Targeting: Do Lower Rates Improve Outreach? Loans Disbursd to Clients with High Poverty Likelihood (>=50\%)

\begin{tabular}{|c|c|c|}
\hline & $(1)$ & $(2)$ \\
\hline Treatment effect Low Interest Rate & $\begin{array}{c}79.63 \\
(122.7)\end{array}$ & \\
\hline Treatment effect Low Interest Rate (Year 1) & & $\begin{array}{c}58.16 \\
(107.9)\end{array}$ \\
\hline Treatment effect Low Interest Rate (Year 2) & & $\begin{array}{c}84.43 \\
(130.0)\end{array}$ \\
\hline Treatment effect Low Interest Rate (Year 3) & & $\begin{array}{c}119.3 \\
(146.3)\end{array}$ \\
\hline P-value: Treatment $* 1$ st year $=$ Treatment $* 2$ nd year & & 0.416 \\
\hline P-value: Treatment $* 2$ nd year $=$ Treatment* 3 rd year & & 0.200 \\
\hline P-value: Treatment* 1 st year=Treatment $* 3$ rd year & & 0.260 \\
\hline P-value: Treatment (high povlik= low povlik) & 0.624 & \\
\hline P-value: Treatment*1year (high povlik=low povlik) & & 0.924 \\
\hline P-value: Treatment*2year (high povlik=low povlik) & & 0.605 \\
\hline P-value: Treatment*3year (high povlik=low povlik) & & 0.358 \\
\hline Treatment effect estimated by: & Low & Low*Year \\
\hline Control for low interest rate branch & $\mathrm{n}$ & $\mathrm{n}$ \\
\hline Fixed effects for month-year & $\mathrm{y}$ & $\mathrm{y}$ \\
\hline Fixed effects for region & $\mathrm{n}$ & $\mathrm{n}$ \\
\hline Includes controls for values of dependent variable in pre-treatment $\mathrm{m}$ & & \\
\hline \& April 2007) & $\mathrm{n}$ & $\mathrm{n}$ \\
\hline Includes pre-treatment observations & $\mathrm{n}$ & $\mathrm{n}$ \\
\hline Mean of dependent variable for high-rate regions (treatment period) & \multicolumn{2}{|c|}{614.486} \\
\hline Point elasticity & -1.14 & \\
\hline Point elasticity year 1 & & -0.97 \\
\hline Point elasticity year 2 & & -1.14 \\
\hline Point elasticity year 3 & & -1.42 \\
\hline $\mathrm{N}$ & & \\
\hline
\end{tabular}

Each column reports results for an OLS regression of number of loans for clients with high poverty likelihood on the variables shown or summarized in the rows. Unit of observation is the region-month, and unit of randomization is the region, so standard errors allow for clustering at the region level. Treatment was implemented on May 16, 2007. The month of May 2007 is excluded because the experiment started in the middle of the month. Post $=1$ for the time period of June 1,2007 to October 31 , 2009. Pre-treatment months are March and April 2007. Poverty likelihood is calculated using household information about the type of floors, water source, cooking fuel, phone ownership and whether children go to school or not. * significant at $10 \%$; ** significant at $5 \% ; * * *$ significant at $1 \%$. 
Table 5. Loan Amount Disbursed (in M\$1,000s)

\begin{tabular}{|c|c|c|c|c|c|c|}
\hline & $(1)$ & $(2)$ & (3) & $(4)$ & $(5)$ & (6) \\
\hline Treatment effect Low Interest Rate & $\begin{array}{l}1,979 * * \\
(759.4)\end{array}$ & $\begin{array}{l}1,960 * * \\
(777.3)\end{array}$ & $\begin{array}{c}1,920^{* * *} \\
(640.4)\end{array}$ & & & \\
\hline Treatment effect Low Interest Rate (Year 1) & & & & $\begin{array}{l}984.0^{* *} \\
(453.8)\end{array}$ & $\begin{array}{l}1,006^{* *} \\
(469.8)\end{array}$ & $\begin{array}{l}930.3 * * \\
(433.5)\end{array}$ \\
\hline Treatment effect Low Interest Rate (Year 2) & & & & $\begin{array}{l}2,187 * * \\
(897.8)\end{array}$ & $\begin{array}{r}2,135^{* *} \\
(916.7)\end{array}$ & $\begin{array}{c}2,120^{* * *} \\
(754.2)\end{array}$ \\
\hline Treatment effect Low Interest Rate (Year 3) & & & & $\begin{array}{c}3,865 * * * \\
(1,370)\end{array}$ & $\begin{array}{c}3,813 * * * \\
(1,378)\end{array}$ & $\begin{array}{c}3,798 * * * \\
(1,216)\end{array}$ \\
\hline $\begin{array}{l}\text { P-value: Treatment*1st year }=\text { Treatment } * 2 \text { nd year } \\
\text { P-value: Treatment*2nd year }=\text { Treatment*3rd year } \\
\text { P-value: Treatment*1st year=Treatment } * 3 \text { rd year }\end{array}$ & & & & $\begin{array}{l}0.040 \\
0.004 \\
0.010\end{array}$ & $\begin{array}{l}0.054 \\
0.003 \\
0.012\end{array}$ & $\begin{array}{l}0.038 \\
0.003 \\
0.009\end{array}$ \\
\hline & & & & Low*Post* & Low*Post* & \\
\hline Treatment effect estimated by: & Low*Post & Low*Post & Low & Year & Year & Low*Year \\
\hline Control for low interest rate branch & $\mathrm{n}$ & $\mathrm{y}$ & $\mathrm{n}$ & $\mathrm{n}$ & $\mathrm{y}$ & $\mathrm{n}$ \\
\hline Fixed effects for month-year & $\mathrm{y}$ & $\mathrm{y}$ & $\mathrm{y}$ & $\mathrm{y}$ & $\mathrm{y}$ & $\mathrm{y}$ \\
\hline Fixed effects for region & $\mathrm{y}$ & $\mathrm{n}$ & $\mathrm{n}$ & $\mathrm{y}$ & $\mathrm{n}$ & $\mathrm{n}$ \\
\hline $\begin{array}{l}\text { Includes controls for values of dependent variable in pre- } \\
\text { treatment months (March \& April 2007) }\end{array}$ & $\mathrm{n}$ & $\mathrm{n}$ & $\mathrm{y}$ & $\mathrm{n}$ & $\mathrm{n}$ & $\mathrm{y}$ \\
\hline Includes pre-treatment observations & $\mathrm{y}$ & $\mathrm{y}$ & $\mathrm{n}$ & $\mathrm{y}$ & $\mathrm{y}$ & $\mathrm{n}$ \\
\hline Mean of dependent variable for pre-treatment period & \multicolumn{6}{|c|}{6450.85} \\
\hline $\begin{array}{l}\text { Mean of dependent variable for high-rate regions (treatment } \\
\text { period) }\end{array}$ & \multicolumn{6}{|c|}{9115.72} \\
\hline Point elasticity & -1.91 & -1.89 & -1.85 & & & \\
\hline Point elasticity year 1 & & & & -1.15 & -1.18 & -1.09 \\
\hline Point elasticity year 2 & & & & -1.99 & -1.94 & -1.93 \\
\hline Point elasticity year 3 & & & & -2.91 & -2.87 & -2.86 \\
\hline $\mathrm{N}$ & 2,469 & 2,469 & 2,313 & 2,469 & 2,469 & 2,313 \\
\hline
\end{tabular}

Each column reports results for an OLS regression of loan amount on the variables shown or summarized in the rows. Unit of observation is the region-month, and unit of randomization is the region, so standard errors allow for clustering at the region level. Treatment was implemented on May 16, 2007. The month of May 2007 is excluded because the experiment started in the middle of the month. Post $=1$ for the time period of June 1, 2007 to October 31, 2009. Pre-treatment months are March and April 2007. Loan amounts are in Mexican pesos $(\$ 1,000 \mathrm{~s})$. * significant at $10 \%$; * significant at $5 \%$; *** significant at $1 \%$. 
Table 6. Does the Compartamos Demand Increase Crowd-out Other Borrowing?

\begin{tabular}{|c|c|c|c|}
\hline $\begin{array}{r}\text { Dependent Variable: } \\
\text { Data source: } \\
\text { Data includes Compartamos?: }\end{array}$ & $\begin{array}{c}\text { Number of Loans } \\
\text { Circulo Bureau } \\
\text { No } \\
(1) \\
\end{array}$ & $\begin{array}{c}\text { Number of Loans } \\
\text { Official Bureau } \\
\text { Yes } \\
(2) \\
\end{array}$ & $\begin{array}{c}\text { Number of Loans } \\
\text { Compartamos } \\
(3) \\
\end{array}$ \\
\hline Post & $\begin{array}{c}12,232^{* * *} \\
(1,801)\end{array}$ & $\begin{array}{c}70,837 * * * \\
(8,862)\end{array}$ & $\begin{array}{c}1,992 * * * \\
(280.5)\end{array}$ \\
\hline Low Interest Rate & $\begin{array}{c}1,708 \\
(1,180)\end{array}$ & $\begin{array}{c}28,787 \\
(35,077)\end{array}$ & $\begin{array}{c}148.3 \\
(520.3)\end{array}$ \\
\hline Post*Low Interest Rate & $\begin{array}{c}4,440 \\
(3,101)\end{array}$ & $\begin{array}{c}18,889 \\
(15,096)\end{array}$ & $\begin{array}{c}788.3 * \\
(427.0)\end{array}$ \\
\hline $\begin{array}{l}\text { Mean of dependent variable for high-rate regions (pre } \\
\text { and post treatment period) } \\
\text { Point Elasticity } \\
\text { N }\end{array}$ & $\begin{array}{l}10,694.52 \\
-3.65 \\
158\end{array}$ & $\begin{array}{l}136,778.24 \\
-1.21 \\
158\end{array}$ & $\begin{array}{c}4,382.48 \\
-1.58 \\
158\end{array}$ \\
\hline
\end{tabular}


Table 7. Delinquency: Proportion of Lending Groups Delinquent

\begin{tabular}{|c|c|c|c|c|c|c|}
\hline & \multicolumn{3}{|c|}{$\begin{array}{c}\text { Delinquency proportion (Loan payment late }>0 \\
\text { day) }\end{array}$} & \multicolumn{3}{|c|}{$\begin{array}{l}\text { Delinquency proportion (Loan payment late } \\
\qquad>90 \text { days) }\end{array}$} \\
\hline & $\begin{array}{c}\text { All groups } \\
\text { (1) }\end{array}$ & $\begin{array}{c}\text { New groups } \\
(2)\end{array}$ & $\begin{array}{c}\text { Groups }>75 \% \\
\text { new members } \\
(3)\end{array}$ & $\begin{array}{c}\text { All groups } \\
(4)\end{array}$ & $\begin{array}{c}\text { New groups } \\
\text { (5) }\end{array}$ & $\begin{array}{c}\text { Groups }>75 \% \\
\text { new members } \\
(6)\end{array}$ \\
\hline \multirow[t]{2}{*}{ Low interest rate } & -0.00935 & -0.0171 & -0.00815 & -0.0159 & -0.0163 & -0.0115 \\
\hline & $(0.0172)$ & $(0.0202)$ & $(0.0176)$ & $(0.0150)$ & $(0.0211)$ & $(0.0172)$ \\
\hline Fixed effects for month-year & $\mathrm{y}$ & $\mathrm{y}$ & $\mathrm{y}$ & $\mathrm{y}$ & $\mathrm{y}$ & $\mathrm{y}$ \\
\hline $\begin{array}{l}\text { Mean of dependent variable for high-rate regions } \\
\text { (treatment period) }\end{array}$ & 0.142 & 0.190 & 0.151 & 0.098 & 0.157 & 0.097 \\
\hline $\mathrm{N}$ & 2,313 & 2,312 & 2,311 & 2,150 & 2,066 & 2,102 \\
\hline
\end{tabular}


Table 8. Income, Costs, and Profits (M\$ 1,000s)

\begin{tabular}{|c|c|c|c|c|c|c|}
\hline & \multicolumn{2}{|c|}{ Income } & \multicolumn{2}{|c|}{ Costs } & \multicolumn{2}{|c|}{ Profits } \\
\hline & $(1)$ & $(2)$ & $(3)$ & $(4)$ & $(5)$ & $(6)$ \\
\hline Treatment effect Low Interest Rate & $\begin{array}{c}64.56 \\
(81.41)\end{array}$ & & $\begin{array}{l}80.26^{* *} \\
(35.96)\end{array}$ & & $\begin{array}{l}-44.56 \\
(54.57)\end{array}$ & \\
\hline Treatment effect Low Interest Rate (Year 1) & & $\begin{array}{l}-3.495 \\
(53.45)\end{array}$ & & $\begin{array}{c}29.33 \\
(27.41)\end{array}$ & & $\begin{array}{l}-62.45 \\
(41.95)\end{array}$ \\
\hline Treatment effect Low Interest Rate (Year 2) & & $\begin{array}{c}77.54 \\
(96.29)\end{array}$ & & $\begin{array}{l}96.29 * * \\
(43.26)\end{array}$ & & $\begin{array}{l}-47.06 \\
(63.39)\end{array}$ \\
\hline \multirow[t]{2}{*}{ Treatment effect Low Interest Rate (Year 3) } & & $\begin{array}{c}195.5 \\
(147.3)\end{array}$ & & $\begin{array}{l}163.1 * * * \\
(57.42)\end{array}$ & & $\begin{array}{c}4.065 \\
(95.77)\end{array}$ \\
\hline & & Low* & & Low* & & Low* \\
\hline Treatment effect estimated by: & Low & Year & Low & Year & Low & Year \\
\hline Control for low interest rate branch & $\mathrm{n}$ & $\mathrm{n}$ & $\mathrm{n}$ & $\mathrm{n}$ & $\mathrm{n}$ & $\mathrm{n}$ \\
\hline Fixed effects for month-year & $\mathrm{y}$ & $\mathrm{y}$ & $\mathrm{y}$ & $\mathrm{y}$ & $\mathrm{y}$ & $\mathrm{y}$ \\
\hline Fixed effects for region & $\mathrm{n}$ & $\mathrm{n}$ & $\mathrm{n}$ & $\mathrm{n}$ & $\mathrm{n}$ & $\mathrm{n}$ \\
\hline $\begin{array}{l}\text { Includes controls for values of dependent } \\
\text { variable in pre-treatment months }\end{array}$ & & & & & & \\
\hline Includes pre-treatment observations & $\begin{array}{l}\mathrm{y} \\
\mathrm{n}\end{array}$ & $\begin{array}{l}\mathrm{y} \\
\mathrm{n}\end{array}$ & $\begin{array}{l}\mathrm{y} \\
\mathrm{n}\end{array}$ & $\begin{array}{l}\mathrm{y} \\
\mathrm{n}\end{array}$ & $\begin{array}{l}\mathrm{y} \\
\mathrm{n}\end{array}$ & $\begin{array}{l}\mathrm{y} \\
\mathrm{n}\end{array}$ \\
\hline $\begin{array}{l}\text { Mean of dependent variable for high-rate regions } \\
\text { (treatment period) }\end{array}$ & $12^{\prime}$ & 66 & & 47 & & \\
\hline $\mathrm{N}$ & & & & & & \\
\hline
\end{tabular}

Each column reports results for an OLS regression of Income, Costs and Profits on the variables shown or summarized in the rows. Unit of observation is the region-month, and unit of randomization is the region, so standard errors allow for clustering at the region level. Treatment was implemented on May 16, 2007. The month of May 2007 is excluded because the experiment started in the middle of the month. Post $=1$ for the time period of June 1, 2007 to October 31, 2009. Pre-treatment months are March and April 2007. Total costs is the sum of all itemized operating costs reported per branch office (summed by region) plus charge-offs and 9.58\%(2007,2008) or 6.31\% (2009) of the outstanding balance as approximated cost of funds, accumulated over a month and summed by region. Interest Income is the total income realized from the group lending product per branch office accumulated over a month and summed by region. Profit is calculated as: profit $=($ interest income) - (total costs) + (changes in the amount due of irrecuperable accounts). The latter term is basically recoveries on charged-off loans. All amounts are in Mexican pesos $(\$ 1,000 \mathrm{~s})$. The results for profits and total costs are robust to changes in their definitions, such as definitions excluding the changes in the amount due after an account becomes irrecuperable. * significant at $10 \%$; ** significant at 5\%; *** significant at $1 \%$. 
Table 9. Competitor (Non-)Response

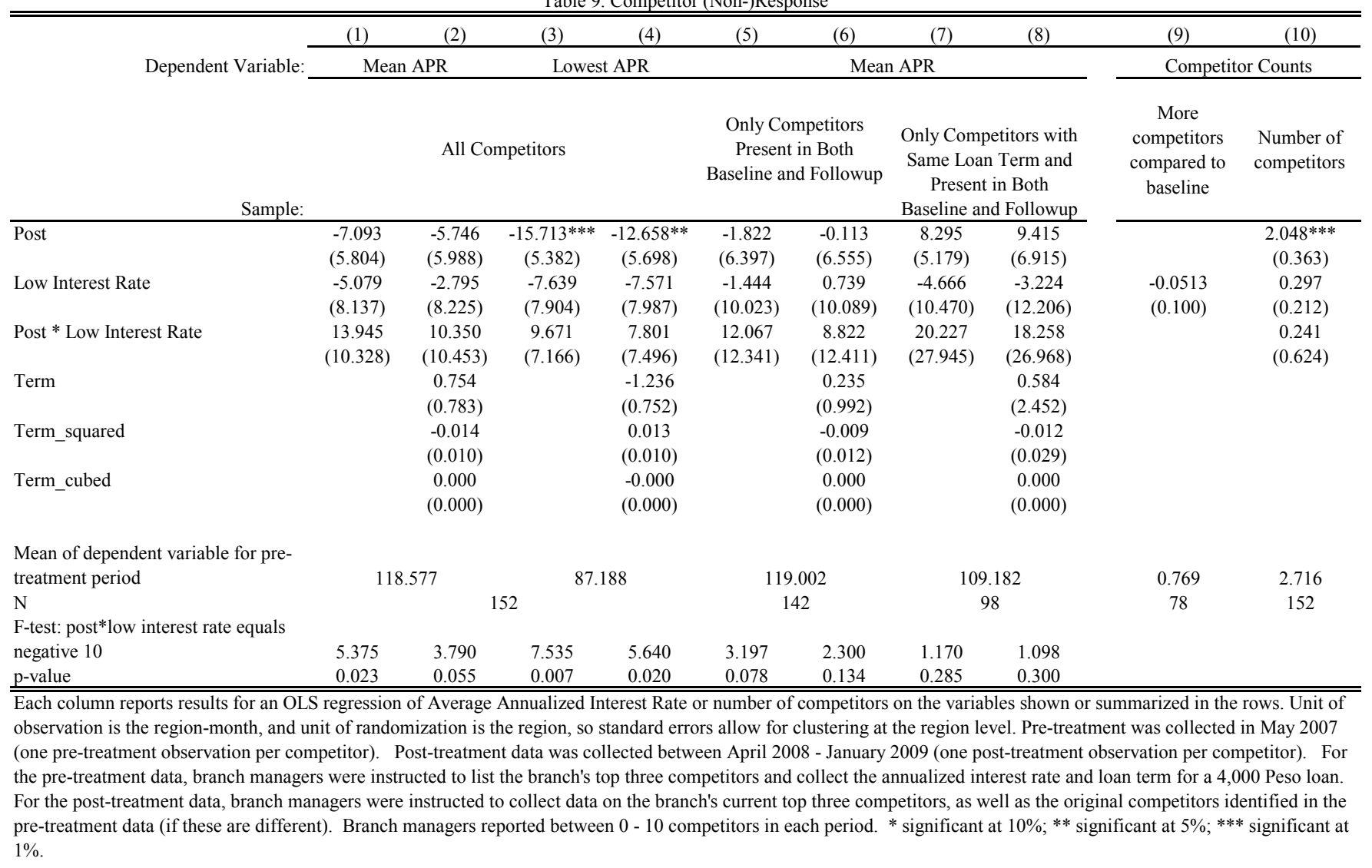


Appendix Table 1. Log(Loans Disbursed) : Compare to Table 3

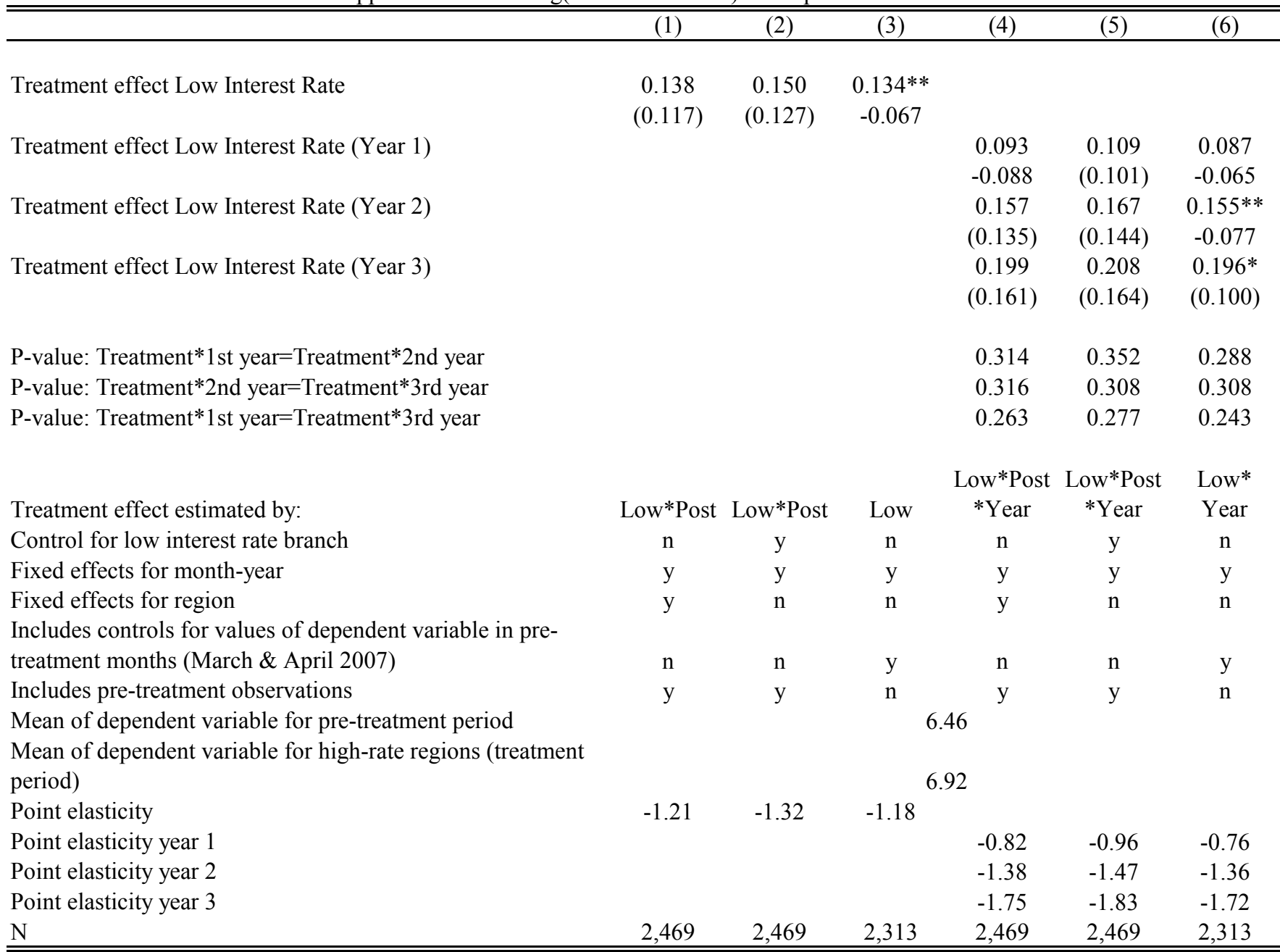

Each column reports results for an OLS regression of the log of number of loans on the variables shown or summarized in the rows. Unit of observation is the region-month, and unit of randomization is the region, so standard errors allow for clustering at the region level. Treatment was implemented on May 16, 2007. The month of May 2007 is excluded because the experiment started in the middle of the month. Post $=1$ for the time period of June 1, 2007 to October 31, 2009. Pre-treatment months are March and April 2007. * significant at 10\%; ** significant at 5\%; *** significant at $1 \%$. 
Treatment effect Low Interest Rate

Treatment effect Low Interest Rate (Year 1)

Treatment effect Low Interest Rate (Year 2)

Treatment effect Low Interest Rate (Year 3)

P-value: Treatment $* 1$ st year $=$ Treatment $* 2$ nd year

P-value: Treatment*2nd year $=$ Treatment*3rd year

P-value: Treatment*1st year $=$ Treatment*3rd year

Treatment effect estimated by:

Control for low interest rate branch

Fixed effects for month-year

Fixed effects for region

Includes controls for values of dependent variable in pretreatment months (March \& April 2007)

Includes pre-treatment observations

Mean of dependent variable for pre-treatment period

Mean of dependent variable for high-rate regions (treatment period)

Point elasticity

Point elasticity year 1

Point elasticity year 2

Point elasticity year 3

$\mathrm{N}$ the rows. Unit of observation is the region-month, and unit of randomization is the region, the region level. Treatment was implemented on May 16, 2007. The month of May 2007 is excluded because the experiment started in the middle of the month. Post $=1$ for the time period of June 1, 2007 to October 31, 2009. Pre-treatment months are March and April 2007. Retained clients are defined as those who get a loan in that month but had received loans previously. $*$ significant at $10 \% ; * *$ significant at $5 \% ; * * *$ significant at $1 \%$.

$\begin{array}{ccc}154.9^{* *} & 154.6^{* *} & 153.3^{* *} \\ (67.15) & (70.47) & (61.86)\end{array}$

$\begin{array}{ccc}72.48 * & 75.96^{*} & 71.21^{*} \\ (40.26) & (43.54) & (38.93) \\ 170.5 * * & 167.1 * * & 168.2 * * \\ (79.75) & (83.17) & (73.56) \\ 315.3 * * & 312.0 * * & 313.1 * * * \\ (124.9) & (126.8) & (117.3)\end{array}$

$\begin{array}{lll}0.074 & 0.095 & 0.070 \\ 0.010 & 0.009 & 0.009 \\ 0.021 & 0.024 & 0.019\end{array}$

$\begin{array}{ccc}\text { Low*Post } & \text { Low }{ }^{*} \text { Post } & \text { Low } \\ \mathrm{n} & \mathrm{y} & \mathrm{n} \\ \mathrm{y} & \mathrm{y} & \mathrm{y} \\ \mathrm{y} & \mathrm{n} & \mathrm{n}\end{array}$

Low*Post Low*Post Low*

*Year *Year Year

$\mathrm{n} \quad \mathrm{y} \quad \mathrm{n}$

$\begin{array}{lll}\mathrm{y} & \mathrm{y} & \mathrm{y}\end{array}$

$\mathrm{n} \quad \mathrm{n} \quad \mathrm{y}$

y $\quad y$

$-1.44$

$-1.44$

$-1.43$

$\begin{array}{lll}-0.81 & -0.85 & -0.80 \\ -1.51 & -1.48 & -1.49 \\ -2.28 & -2.25 & -2.26 \\ 2,469 & 2,469 & 2,313\end{array}$

$\begin{array}{llllll}2,469 & 2,469 & 2,313 & 2,469 & 2,469 & 2,313\end{array}$




\begin{tabular}{|c|c|c|c|c|c|c|}
\hline & $(1)$ & $(2)$ & $(3)$ & $(4)$ & $(5)$ & $(6)$ \\
\hline Treatment effect Low Interest Rate & $\begin{array}{l}124.5 * * \\
(51.09)\end{array}$ & $\begin{array}{l}124.2 * * \\
(51.55)\end{array}$ & $\begin{array}{l}103.6^{* *} \\
(45.21)\end{array}$ & & & \\
\hline Treatment effect Low Interest Rate (Year 1) & & & & $\begin{array}{l}50.76^{*} \\
(25.94)\end{array}$ & $\begin{array}{l}52.61 * \\
(26.83)\end{array}$ & $\begin{array}{c}29.78 \\
(27.44)\end{array}$ \\
\hline Treatment effect Low Interest Rate (Year 2) & & & & $\begin{array}{l}142.6 * * \\
(60.65)\end{array}$ & $\begin{array}{l}140.4^{* *} \\
(60.90)\end{array}$ & $\begin{array}{l}121.3 * * \\
(53.24)\end{array}$ \\
\hline Treatment effect Low Interest Rate (Year 3) & & & & $\begin{array}{l}258.0 * * \\
(101.1)\end{array}$ & $\begin{array}{l}255.8 * * \\
(100.6)\end{array}$ & $\begin{array}{l}236.7^{* *} \\
(92.19)\end{array}$ \\
\hline Treatment effect estimated by: & Low*Post & Low*Post & Low & $\begin{array}{l}\text { Low*Post } \\
\text { *Year }\end{array}$ & $\begin{array}{l}\text { Low*Post } \\
\text { *Year }\end{array}$ & $\begin{array}{l}\text { Low* } \\
\text { Year }\end{array}$ \\
\hline Control for low interest rate branch & $\mathrm{n}$ & $\mathrm{y}$ & $\mathrm{n}$ & $\mathrm{n}$ & $\mathrm{y}$ & $\mathrm{n}$ \\
\hline Fixed effects for month-year & $\mathrm{y}$ & $\mathrm{y}$ & $\mathrm{y}$ & $\mathrm{y}$ & $\mathrm{y}$ & $\mathrm{y}$ \\
\hline Fixed effects for region & $\mathrm{y}$ & $\mathrm{n}$ & $\mathrm{n}$ & $\mathrm{y}$ & $\mathrm{n}$ & $\mathrm{n}$ \\
\hline $\begin{array}{l}\text { Includes controls for values of dependent variable in pre- } \\
\text { treatment months (March \& April 2007) }\end{array}$ & $\mathrm{n}$ & $\mathrm{n}$ & $\mathrm{y}$ & $\mathrm{n}$ & $\mathrm{n}$ & $\mathrm{y}$ \\
\hline Includes pre-treatment observations & $\mathrm{y}$ & $\mathrm{y}$ & $\mathrm{n}$ & $\mathrm{y}$ & $\mathrm{y}$ & $\mathrm{n}$ \\
\hline $\begin{array}{l}\text { Mean of dependent variable for pre-treatment period } \\
\text { Mean of dependent variable for high-rate regions (treatment } \\
\text { period) }\end{array}$ & \multicolumn{6}{|c|}{578.09} \\
\hline Point elasticity & -1.89 & -1.64 & -1.37 & & & \\
\hline Point elasticity year 1 & & & & -0.79 & -0.82 & -0.47 \\
\hline Point elasticity year 2 & & & & -1.77 & -1.74 & -1.51 \\
\hline Point elasticity year 3 & & & & -2.74 & -2.71 & -2.51 \\
\hline $\mathrm{N}$ & 2,469 & 2,469 & 2,313 & 2,469 & 2,469 & 2,313 \\
\hline
\end{tabular}

Each column reports results for an OLS regression of number of loans for clients with high education on the variables shown or summarized in the rows. Unit of observation is the region-month, and unit of randomization is the region, so standard errors allow for clustering at the region level. Treatment was implemented on May 16, 2007. The month of May 2007 is excluded because the experiment started in the middle of the month. Post $=1$ for the time period of June 1, 2007 to October 31, 2009. Pre-treatment months are March and April 2007. Clients with high education are defined as those who completed high school. * significant at $10 \% ; * *$ significant at $5 \% ; * * *$ significant at $1 \%$. 
Appendix Table 4. Pricing as Targeting: Do Lower Rates Improve Outreach? Clients with low poverty likelihood $(>=50 \%)$ (Compare to Table $4 \mathrm{c})$

\begin{tabular}{lcc}
\hline \hline & $(1)$ & $(2)$ \\
\hline Treatment effect Low Interest Rate & 154.8 & \\
& & \\
Treatment effect Low Interest Rate (Year 1) & & 70.07 \\
& & $(63.01)$ \\
Treatment effect Low Interest Rate (Year 2) & & $(107.6)$ \\
& & $316.3^{* *}$ \\
Treatment effect Low Interest Rate (Year 3) & & $(156.8)$ \\
& & \\
Treatment effect estimated by: & Low & $\mathrm{n}$ \\
Control for low interest rate branch & $\mathrm{y}$ & $\mathrm{y}$ \\
Fixed effects for month-year & $\mathrm{n}$ & $\mathrm{n}$ \\
Fixed effects for region & & $\mathrm{n}$ \\
Includes controls for values of dependent variable in pre-treatment months & $\mathrm{n}$ \\
(March \& April 2007) & & $\mathrm{n}$ \\
Includes pre-treatment observations & 579.687 & \\
Mean of dependent variable for high-rate regions (treatment period) & -2.35 & -1.48 \\
Point elasticity & & -2.36 \\
Point elasticity year 1 & & -3.36 \\
Point elasticity year 2 & & 2,313 \\
Point elasticity year 3 & & \\
N & & \\
\hline \hline
\end{tabular}

$\overline{\text { Each column reports results for an OLS regression of number of loans for clients with low poverty likelihood on the }}$ variables shown or summarized in the rows. Unit of observation is the region-month, and unit of randomization is the region, so standard errors allow for clustering at the region level. Treatment was implemented on May 16, 2007. The month of May 2007 is excluded because the experiment started in the middle of the month. Post $=1$ for the time period of June 1, 2007 to October 31, 2009. Pre-treatment months are March and April 2007. New clients are defined as those who get their first loan ever in that month. Poverty likelihood is calculated using household information about the type of floors, water source, cooking fuel, phone ownership and whether children go to school or not. * significant at $10 \%$; ** significant at $5 \% ; * * *$ significant at $1 \%$. 


\begin{tabular}{|c|c|c|c|c|c|c|}
\hline & $(1)$ & $(2)$ & (3) & $(4)$ & $(5)$ & (6) \\
\hline Treatment effect Low Interest Rate & $\begin{array}{c}0.190 \\
(0.137)\end{array}$ & $\begin{array}{c}0.201 \\
(0.151)\end{array}$ & $\begin{array}{c}0.188 * * \\
-0.074\end{array}$ & & & \\
\hline Treatment effect Low Interest Rate (Year 1) & & & & $\begin{array}{c}0.126 \\
(0.103)\end{array}$ & $\begin{array}{c}0.144 \\
(0.121)\end{array}$ & $\begin{array}{l}0.123^{*} \\
-0.072\end{array}$ \\
\hline Treatment effect Low Interest Rate (Year 2) & & & & $\begin{array}{c}0.219 \\
(0.157)\end{array}$ & $\begin{array}{c}0.225 \\
(0.170)\end{array}$ & $\begin{array}{l}0.217^{* *} \\
-0.085\end{array}$ \\
\hline Treatment effect Low Interest Rate (Year 3) & & & & $\begin{array}{c}0.276 \\
(0.189)\end{array}$ & $\begin{array}{c}0.283 \\
(0.195)\end{array}$ & $\begin{array}{l}0.275^{* *} \\
(0.112)\end{array}$ \\
\hline $\begin{array}{l}\text { P-value: Treatment } * 1 \text { st year }=\text { Treatment } * 2 \text { nd year } \\
\text { P-value: Treatment } * 2 \text { nd year }=\text { Treatment } * 3 \text { rd year } \\
\text { P-value: Treatment } * 1 \text { st year }=\text { Treatment } * 3 \text { rd year }\end{array}$ & & & & $\begin{array}{l}0.197 \\
0.232 \\
0.176\end{array}$ & $\begin{array}{l}0.233 \\
0.225 \\
0.191\end{array}$ & $\begin{array}{l}0.181 \\
0.225 \\
0.163\end{array}$ \\
\hline Treatment effect estimated by. & Low $*$ Post & Low*Post & L ow & $\begin{array}{l}\text { Low*Post } \\
* \text { Y }\end{array}$ & $\begin{array}{l}\text { Low*Post } \\
* \text { Year }\end{array}$ & Low* Year \\
\hline Control for low interest rate branch & $\mathrm{n}$ & $\mathrm{y}$ & $\mathrm{n}$ & $\mathrm{n}$ & $\mathrm{y}$ & $\mathrm{n}$ \\
\hline Fixed effects for month-year & $\mathrm{y}$ & $\mathrm{y}$ & $\mathrm{y}$ & $\mathrm{y}$ & $\mathrm{y}$ & $\mathrm{y}$ \\
\hline Fixed effects for region & $\mathrm{y}$ & $\mathrm{n}$ & $\mathrm{n}$ & $\mathrm{y}$ & $\mathrm{n}$ & $\mathrm{n}$ \\
\hline $\begin{array}{l}\text { Includes controls for values of dependent variable in pre- } \\
\text { treatment months (March \& April 2007) }\end{array}$ & $\mathrm{n}$ & $\mathrm{n}$ & $\mathrm{y}$ & $\mathrm{n}$ & $\mathrm{n}$ & $\mathrm{y}$ \\
\hline Includes pre-treatment observations & $\mathrm{y}$ & $\mathrm{y}$ & $\mathrm{n}$ & $\mathrm{y}$ & $\mathrm{y}$ & $\mathrm{n}$ \\
\hline $\begin{array}{l}\text { Mean of dependent variable for pre-treatment period } \\
\text { Mean of dependent variable for high-rate regions } \\
\text { (treatment period) }\end{array}$ & \multicolumn{6}{|c|}{8.80} \\
\hline Point elasticity & -1.67 & -1.77 & -1.65 & & & \\
\hline Point elasticity year 1 & & & & -1.11 & -1.26 & -1.08 \\
\hline Point elasticity year 2 & & & & -1.92 & -1.98 & -1.91 \\
\hline Point elasticity year 3 & & & & -2.42 & -2.49 & -2.42 \\
\hline $\mathrm{N}$ & 2,469 & 2,469 & 2,313 & 2,469 & 2,469 & 2,313 \\
\hline
\end{tabular}

Each column reports results for an OLS regression of Loan amount on the variables shown or summarized in the rows. Unit of observation is the region-month, and unit of randomization is the region, so standard errors allow for clustering at the region level. Treatment was implemented on May 16, 2007. The month of May 2007 is excluded because the experiment started in the middle of the month. Post $=1$ for the time period of June 1, 2007 to October 31, 2009. Pre-treatment months are March and April 2007. Loan amounts are in Mexican pesos (\$1,000s). * significant at 10\%; ** significant at 5\%; *** significant at $1 \%$. 
Appendix Table 6. Proportion of Lending Groups Delinquent, Group-Month Observations (Compare to Table 7)

\begin{tabular}{|c|c|c|c|c|c|c|}
\hline & \multicolumn{3}{|c|}{$\begin{array}{l}\text { Delinquency proportion (Loan payment late }>0 \\
\text { day) }\end{array}$} & \multicolumn{3}{|c|}{$\begin{array}{l}\text { Delinquency proportion (Loan payment late }>90 \\
\text { day) }\end{array}$} \\
\hline & $\begin{array}{c}\text { All groups } \\
\text { (1) } \\
\end{array}$ & $\begin{array}{c}\text { New groups } \\
(2) \\
\end{array}$ & $\begin{array}{l}\text { Groups }>75 \% \\
\text { new members } \\
(3) \\
\end{array}$ & $\begin{array}{c}\text { All groups } \\
\text { (4) } \\
\end{array}$ & $\begin{array}{c}\text { New groups } \\
(5) \\
\end{array}$ & $\begin{array}{l}\text { Groups }>75 \% \\
\text { new members } \\
(6) \\
\end{array}$ \\
\hline \multirow[t]{2}{*}{ Low interest rate } & -0.0200 & -0.0261 & -0.0190 & -0.0196 & -0.0273 & -0.0274 \\
\hline & $(0.0159)$ & $(0.0205)$ & $(0.0178)$ & $(0.0145)$ & $(0.0204)$ & $(0.0215)$ \\
\hline Fixed effects for month-year & $\mathrm{y}$ & $\mathrm{y}$ & $\mathrm{y}$ & $\mathrm{y}$ & y & $\mathrm{y}$ \\
\hline $\begin{array}{l}\text { Mean of dependent variable for high-rate } \\
\text { regions (treatment period) } \\
\mathrm{N}\end{array}$ & $\begin{array}{c}0.133 \\
662,275 \\
\end{array}$ & $\begin{array}{c}0.196 \\
138,724\end{array}$ & $\begin{array}{c}0.145 \\
237,287\end{array}$ & $\begin{array}{c}0.105 \\
152,595\end{array}$ & $\begin{array}{c}0.186 \\
36,675\end{array}$ & $\begin{array}{c}0.130 \\
54,198\end{array}$ \\
\hline
\end{tabular}


Appendix Table 7. Income, Costs, and Profits: Alternative Specifications (Compare to Table 8)

\begin{tabular}{|c|c|c|c|c|c|c|}
\hline & \multicolumn{2}{|c|}{ Income } & \multicolumn{2}{|c|}{ Costs } & \multicolumn{2}{|c|}{ Profits } \\
\hline & (1) & (2) & (3) & (4) & $(5)$ & $(6)$ \\
\hline \multicolumn{7}{|l|}{ Panel A: Equation (1) } \\
\hline Treatment effect Low Interest Rate & $\begin{array}{c}71.50 \\
(87.78)\end{array}$ & & $\begin{array}{c}108.5 * * \\
(44.44)\end{array}$ & & $\begin{array}{l}-36.87 \\
(70.46)\end{array}$ & \\
\hline Treatment effect Low Interest Rate (Year 1) & & $\begin{array}{c}3.432 \\
(53.23)\end{array}$ & & $\begin{array}{l}57.32 * \\
(29.27)\end{array}$ & & $\begin{array}{l}-54.46 \\
(57.21)\end{array}$ \\
\hline Treatment effect Low Interest Rate (Year 2) & & $\begin{array}{c}84.86 \\
(104.0)\end{array}$ & & $\begin{array}{l}124.9 * * \\
(53.58)\end{array}$ & & $\begin{array}{l}-39.49 \\
(78.24)\end{array}$ \\
\hline \multirow[t]{2}{*}{ Treatment effect Low Interest Rate (Year 3) } & & $\begin{array}{c}202.8 \\
(158.0)\end{array}$ & & $\begin{array}{c}191.7 * * * \\
(68.61)\end{array}$ & & $\begin{array}{c}11.63 \\
(110.9)\end{array}$ \\
\hline & & ow*Post* & & Low*Post* & & ow*Post* \\
\hline Treatment effect estimated by: & Low*Post & Year & Low*Post & Year & Low*Post & Year \\
\hline Control for low interest rate branch & $\mathrm{n}$ & $\mathrm{n}$ & $\mathrm{n}$ & $\mathrm{n}$ & $\mathrm{n}$ & $\mathrm{n}$ \\
\hline Fixed effects for month-year & $\mathrm{y}$ & $\mathrm{y}$ & $\mathrm{y}$ & $\mathrm{y}$ & $\mathrm{y}$ & $\mathrm{y}$ \\
\hline \multicolumn{6}{|l|}{ Includes controls for values of dependent } & $\mathrm{y}$ \\
\hline variable in pre-treatment months & $\mathrm{n}$ & $\mathrm{n}$ & $\mathrm{n}$ & $\mathrm{n}$ & $\mathrm{n}$ & $\mathrm{n}$ \\
\hline Includes pre-treatment observations & $\mathrm{y}$ & $\mathrm{y}$ & $\mathrm{y}$ & $\mathrm{y}$ & $\mathrm{y}$ & $\mathrm{y}$ \\
\hline $\begin{array}{l}\text { Mean of dependent variable for high-rate } \\
\text { regions (treatment period) }\end{array}$ & \multicolumn{2}{|c|}{1278.66} & \multicolumn{2}{|c|}{566.47} & \multicolumn{2}{|c|}{714.00} \\
\hline $\mathrm{N}$ & \multicolumn{2}{|c|}{2,469} & \multicolumn{2}{|c|}{2,469} & \multicolumn{2}{|c|}{2,469} \\
\hline \multicolumn{7}{|l|}{ Panel B: Equation (2) } \\
\hline Treatment effect Low Interest Rate & $\begin{array}{c}73.28 \\
(92.99)\end{array}$ & & $\begin{array}{c}106.5^{* *} \\
(44.76)\end{array}$ & & $\begin{array}{l}-33.25 \\
(73.34)\end{array}$ & \\
\hline Treatment effect Low Interest Rate (Year 1) & & $\begin{array}{c}22.29 \\
(177.8)\end{array}$ & & $\begin{array}{l}95.99 * \\
(57.08)\end{array}$ & & $\begin{array}{l}-74.36 \\
(132.9)\end{array}$ \\
\hline Treatment effect Low Interest Rate (Year 2) & & $\begin{array}{c}95.59 \\
(213.6)\end{array}$ & & $\begin{array}{c}159.6 * * \\
(79.73)\end{array}$ & & $\begin{array}{l}-63.53 \\
(152.3)\end{array}$ \\
\hline \multirow[t]{2}{*}{ Treatment effect Low Interest Rate (Year 3) } & & $\begin{array}{c}213.6 \\
(253.1)\end{array}$ & & $\begin{array}{c}226.4 * * \\
(92.72)\end{array}$ & & $\begin{array}{l}-12.41 \\
(178.1)\end{array}$ \\
\hline & & ow*Post* & & Low*Post* & & ow*Post* \\
\hline Treatment effect estimated by: & Low*Post & Year & Low*Post & Year & Low*Post & Year \\
\hline Control for low interest rate branch & $\mathrm{y}$ & $\mathrm{y}$ & $\mathrm{y}$ & $\mathrm{y}$ & $\mathrm{y}$ & $\mathrm{y}$ \\
\hline Fixed effects for month-year & $\mathrm{y}$ & $\mathrm{y}$ & $\mathrm{y}$ & $\mathrm{y}$ & $\mathrm{y}$ & $\mathrm{y}$ \\
\hline Fixed effects for region & $\mathrm{n}$ & $\mathrm{n}$ & $\mathrm{n}$ & $\mathrm{n}$ & $\mathrm{n}$ & $\mathrm{n}$ \\
\hline \multicolumn{7}{|l|}{$\begin{array}{l}\text { Includes controls for values of dependent } \\
\text { variable in pre-treatment months (March \& }\end{array}$} \\
\hline April 2007) & $\mathrm{n}$ & $\mathrm{n}$ & $\mathrm{n}$ & $\mathrm{n}$ & $\mathrm{n}$ & $\mathrm{n}$ \\
\hline Includes pre-treatment observations & $\mathrm{y}$ & $\mathrm{y}$ & $\mathrm{y}$ & $\mathrm{y}$ & $\mathrm{y}$ & $\mathrm{y}$ \\
\hline $\begin{array}{l}\text { Mean of dependent variable for high-rate } \\
\text { regions (treatment period) }\end{array}$ & \multicolumn{2}{|c|}{1002.36} & \multicolumn{2}{|c|}{549.13} & \multicolumn{2}{|c|}{453.22} \\
\hline $\mathrm{N}$ & \multicolumn{2}{|c|}{2,469} & \multicolumn{2}{|c|}{2,469} & \multicolumn{2}{|c|}{2,469} \\
\hline
\end{tabular}

Each column reports results for an OLS regression of Income, Costs and Profits on the variables shown or summarized in the rows. Unit of observation is the region-month, and unit of randomization is the region, so standard errors allow for clustering at the region level. Treatment was implemented on May 16, 2007. The month of May 2007 is excluded because the experiment started in the middle of the month. Post $=1$ for the time period of June 1, 2007 to October 31, 2009. Pre-treatment months are March and April 2007. Total costs is the sum of all itemized operating costs reported per branch office (summed by region) plus charge-offs and $9.58 \%(2007,2008)$ or $6.31 \%$ (2009) of the outstanding balance as approximate cost of funds, accumulated over a month and summed by region. Interest Income is the total income realized from the group lending product per branch office accumulated over a month and summed by region. Profit is calculated as: profit $=$ interest income - total costs + changes in the amount due of irrecuperable accounts. All amounts are in Mexican pesos $(\$ 1,000 \mathrm{~s})$. The results for profits and total costs are robust to changes in their definitions, such as definitions excluding the changes in the amount due after an account becomes irrecuperable. $*$ significant at $10 \% ; * *$ significant at $5 \%$;** significant at $1 \%$. 
Appendix Table 8. Personnel Costs

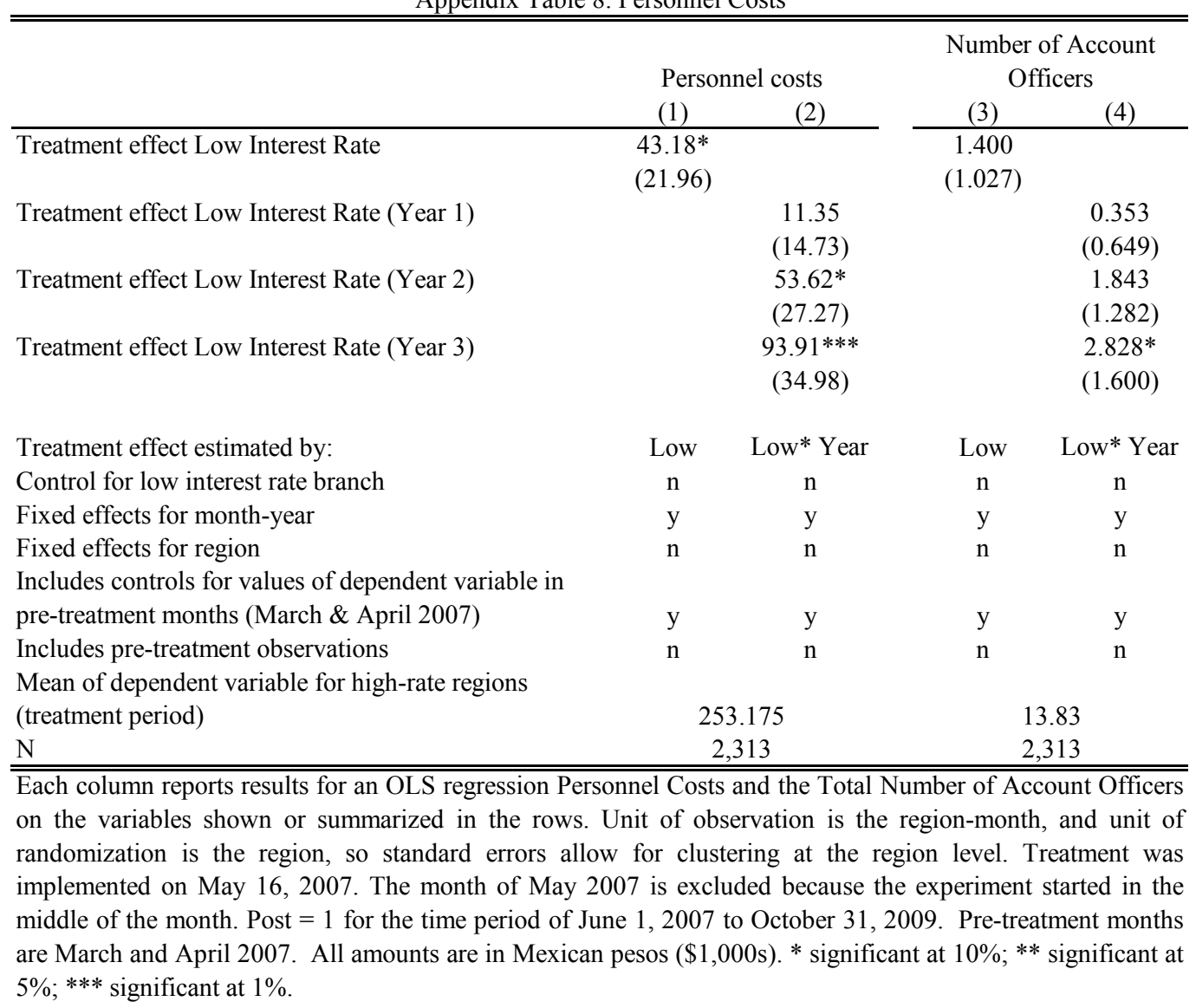




\begin{tabular}{lcc}
\hline \hline & & \\
& Total Costs & Personnel Costs \\
& $(1)$ & $(2)$ \\
\hline Average number of members per group & 2.542 & $-6.172^{*}$ \\
& $(5.865)$ & $(3.612)$ \\
Total number of lending groups & $4.146^{* * *}$ & $1.975^{* * *}$ \\
& $(0.605)$ & $(0.331)$ \\
Fixed effects for month-year & & $\mathrm{y}$ \\
Fixed effects for region & $\mathrm{y}$ & $\mathrm{n}$ \\
& $\mathrm{n}$ & \\
Includes controls for values of dependent variable & & $\mathrm{y}$ \\
in pre-treatment months (March \& April 2007) & $\mathrm{y}$ & $\mathrm{n}$ \\
Includes pre-treatment observations & $\mathrm{n}$ & 296.485 \\
Mean of dependent variable & 639.041 & 16.894 \\
Mean of average number of members per group & 16.894 & 79.028 \\
Mean of total number of lending groups & 79.028 & 2,313 \\
$\mathrm{~N}$ & 2,313 & \\
\hline \hline
\end{tabular}

Each column reports results for an OLS regression of costs on the variables shown or summarized in the rows. Unit of observation is the region-month, and unit of randomization is the region, so standard errors allow for clustering at the region level. Treatment was implemented on May 16, 2007. The month of May 2007 is excluded because the experiment started in the middle of the month. Average number of members per group and total number of lending groups are flow variables. Total costs is the sum of all itemized operating costs reported per branch office (salaries, benefits, bonuses, internal training, external training, and administrative expenses) plus charge-offs and $9.58 \%(2007,2008)$ or $6.31 \%(2009)$ of the outstanding balance as approximate cost of funds, accumulated over a month and summed by region. All amounts are in Mexican pesos $(\$ 1,000 \mathrm{~s})$. The results for profits and total costs are robust to changes in their definitions, such as definitions excluding the changes in the amount due after an account becomes irrecuperable. * significant at $10 \% ; * *$ significant at $5 \% ; * * *$ significant at $1 \%$. 
Appendix Table 10. Number of groups and members per group

\begin{tabular}{|c|c|c|c|c|c|c|c|c|}
\hline & \multicolumn{2}{|c|}{$\begin{array}{l}\text { Total number of } \\
\text { lending groups }\end{array}$} & \multicolumn{2}{|c|}{$\begin{array}{l}\text { Average number of } \\
\text { members per group }\end{array}$} & \multicolumn{2}{|c|}{$\begin{array}{l}\text { Average number of } \\
\text { groups per account } \\
\text { officer }\end{array}$} & \multicolumn{2}{|c|}{$\begin{array}{l}\text { Average number of } \\
\text { clients per account } \\
\text { officer }\end{array}$} \\
\hline & $(1)$ & $(2)$ & (3) & (4) & $(5)$ & $(6)$ & $(7)$ & $(8)$ \\
\hline Treatment effect Low Interest Rate & $\begin{array}{c}8.217 \\
(5.022)\end{array}$ & & $\begin{array}{l}0.662 * \\
(0.336)\end{array}$ & & $\begin{array}{c}0.178 \\
(0.644)\end{array}$ & & $\begin{array}{c}17.28 \\
(13.28)\end{array}$ & \\
\hline $\begin{array}{l}\text { Treatment effect Low Interest Rate } \\
\text { (Year 1) }\end{array}$ & & $\begin{array}{l}2.500 \\
(2.847)\end{array}$ & & $\begin{array}{r}0.587 * * \\
(0.288)\end{array}$ & & $\begin{array}{c}0.491 \\
(0.808)\end{array}$ & & $\begin{array}{c}21.61 \\
(15.85)\end{array}$ \\
\hline $\begin{array}{l}\text { Treatment effect Low Interest Rate } \\
\text { (Year 2) }\end{array}$ & & $\begin{array}{l}9.305 \\
(5.997)\end{array}$ & & $\begin{array}{l}0.680^{*} \\
(0.393)\end{array}$ & & $\begin{array}{l}-0.185 \\
(0.808)\end{array}$ & & $\begin{array}{l}11.43 \\
(16.04)\end{array}$ \\
\hline $\begin{array}{l}\text { Treatment effect Low Interest Rate } \\
\text { (Year 3) }\end{array}$ & & $\begin{array}{l}19.22 * * \\
(9.413)\end{array}$ & & $\begin{array}{l}0.796^{*} \\
(0.441)\end{array}$ & & $\begin{array}{c}0.304 \\
(0.866)\end{array}$ & & $\begin{array}{c}21.01 \\
(16.81)\end{array}$ \\
\hline & & Low* & & Low* & & Low* & & Low* \\
\hline Treatment effect estimated by: & Low & Year & Low & Year & Low & Year & Low & Year \\
\hline Control for low interest rate branch & $\mathrm{n}$ & $\mathrm{n}$ & $\mathrm{n}$ & $\mathrm{n}$ & $\mathrm{n}$ & $\mathrm{n}$ & $\mathrm{n}$ & $\mathrm{n}$ \\
\hline Fixed effects for month-year & $\mathrm{y}$ & $\mathrm{y}$ & $\mathrm{y}$ & $\mathrm{y}$ & $\mathrm{y}$ & $\mathrm{y}$ & $\mathrm{y}$ & $\mathrm{y}$ \\
\hline Fixed effects for region & $\mathrm{n}$ & $\mathrm{n}$ & $\mathrm{n}$ & $\mathrm{n}$ & $\mathrm{n}$ & $\mathrm{n}$ & $\mathrm{n}$ & $\mathrm{n}$ \\
\hline $\begin{array}{l}\text { Includes controls for values of } \\
\text { dependent variable in pre-treatment } \\
\text { months }\end{array}$ & $\mathrm{y}$ & $\mathrm{y}$ & $\mathrm{y}$ & $\mathrm{y}$ & $\mathrm{y}$ & $\mathrm{y}$ & $\mathrm{y}$ & $\mathrm{y}$ \\
\hline Includes pre-treatment observations & $\mathrm{n}$ & $\mathrm{n}$ & $\mathrm{n}$ & $\mathrm{n}$ & $\mathrm{n}$ & $\mathrm{n}$ & $\mathrm{n}$ & $\mathrm{n}$ \\
\hline $\begin{array}{l}\text { Mean of dependent variable for high-rate } \\
\text { regions (treatment period) }\end{array}$ & & & & & & & & \\
\hline $\mathrm{N}$ & & & & & & & & \\
\hline
\end{tabular}

Each column reports results for an OLS regression of the number of lending groups, the average number of members per group, average number of clients and average number of groups per account officer on the variables shown or summarized in the rows. Unit of observation is the regionmonth, and unit of randomization is the region, so standard errors allow for clustering at the region level. Treatment was implemented on May 16, 2007. The month of May 2007 is excluded because the experiment started in the middle of the month. Average number of members per group and total number of lending groups are flow variables. * significant at $10 \%$; ** significant at $5 \%$; ** significant at $1 \%$. 